\title{
Assessment of online water-soluble brown carbon measuring systems for aircraft sampling
}

\author{
Linghan Zeng ${ }^{1}$, Amy P. Sullivan ${ }^{2}$, Rebecca A. Washenfelder ${ }^{3}$, Jack Dibb ${ }^{4}$, Eric Scheuer ${ }^{4}$, Teresa L. Campos ${ }^{5}$, \\ Joseph M. Katich ${ }^{3,6}$, Ezra Levin ${ }^{2,7}$, Michael A. Robinson ${ }^{3,6,8}$, and Rodney J. Weber ${ }^{1}$ \\ ${ }^{1}$ School of Earth and Atmospheric Sciences, Georgia Institute of Technology, Atlanta, GA, USA \\ ${ }^{2}$ Department of Atmospheric Science, Colorado State University, Fort Collins, Colorado, USA \\ ${ }^{3}$ Chemical Sciences Laboratory, National Oceanic and Atmospheric Administration, Boulder, CO, USA \\ ${ }^{4}$ College of Engineering and Physical Sciences, University of New Hampshire, Durham, NH, USA \\ ${ }^{5}$ Atmospheric Chemistry Observations and Modeling Laboratory, National Center for Atmospheric Research, \\ Boulder, CO, USA \\ ${ }^{6}$ Cooperative Institute for Research in Environmental Sciences, University of Colorado Boulder, Boulder, CO, USA \\ ${ }^{7}$ Handix Scientific, Boulder, CO, USA \\ ${ }^{8}$ Department of Chemistry, University of Colorado Boulder, Boulder, CO, USA
}

Correspondence: Rodney J. Weber (rodney.weber@eas.gatech.edu)

Received: 6 May 2021 - Discussion started: 17 May 2021

Revised: 23 August 2021 - Accepted: 26 August 2021 - Published: 1 October 2021

\begin{abstract}
Brown carbon (BrC) consists of particulate organic species that preferentially absorb light at visible and ultraviolet wavelengths. Ambient studies show that as a component of aerosol particles, $\mathrm{BrC}$ affects photochemical reaction rates and regional to global climate. Some organic chromophores are especially toxic, linking $\mathrm{BrC}$ to adverse health effects. The lack of direct measurements of $\mathrm{BrC}$ has limited our understanding of its prevalence, sources, evolution, and impacts. We describe the first direct, online measurements of water-soluble $\mathrm{BrC}$ on research aircraft by three separate instruments. Each instrument measured light absorption over a broad wavelength range using a liquid waveguide capillary cell (LWCC) and grating spectrometer, with particles collected into water by a particle-into-liquid sampler (CSU PILS-LWCC and NOAA PILS-LWCC) or a mist chamber (MC-LWCC). The instruments were deployed on the NSF C130 aircraft during WE-CAN 2018 as well as the NASA DC8 and the NOAA Twin Otter aircraft during FIREX-AQ 2019, where they sampled fresh and moderately aged wildfire plumes. Here, we describe the instruments, calibrations, data analysis and corrections for baseline drift and hysteresis. Detection limits $(3 \sigma)$ at $365 \mathrm{~nm}$ were $1.53 \mathrm{Mm}^{-1}$ (MC-LWCC; 2.5 min sampling time), $0.89 \mathrm{Mm}^{-1}$ (CSU PILS-LWCC; $30 \mathrm{~s}$ sampling time), and $0.03 \mathrm{Mm}^{-1}$ (NOAA PILS-LWCC; $30 \mathrm{~s}$
\end{abstract}

sampling time). Measurement uncertainties were $28 \%$ (MCLWCC), $12 \%$ (CSU PILS-LWCC), and $11 \%$ (NOAA PILSLWCC). The MC-LWCC system agreed well with offline measurements from filter samples, with a slope of 0.91 and $R^{2}=0.89$. Overall, these instruments provide soluble $\mathrm{BrC}$ measurements with specificity and geographical coverage that is unavailable by other methods, but their sensitivity and time resolution can be challenging for aircraft studies where large and rapid changes in $\mathrm{BrC}$ concentrations may be encountered.

\section{Introduction}

\subsection{Importance of brown carbon}

Organic compounds are a major component of ambient aerosol that affect atmospheric visibility, Earth's radiation balance and human health. In the past, all organic aerosol (OA) compounds were assumed to only scatter light and exert a cooling effect (Koch et al., 2007; Myhre et al., 2008). Recent studies have shown that a fraction of OA absorbs light with a strong wavelength dependence (Andreae and Gelencsér, 2006; Lack and Cappa, 2010). These absorbing OA com- 
ponents are referred to as brown carbon $(\mathrm{BrC})$ because they have a brown or yellow appearance when concentrated, resulting from higher absorption at shorter visible and ultraviolet (UV) wavelengths. This absorption offsets some portion of the scattering by OA. Modeling studies have suggested a non-negligible influence by $\mathrm{BrC}$ (Feng et al., 2013; Saleh et al., 2015; Zhang et al., 2017, 2020). Actual global measurements of $\mathrm{BrC}$, using the analytical methods discussed here, have shown that $\mathrm{BrC}$ can contribute up to $48 \%$ of the overall warming effect globally by absorbing carbonaceous aerosols (i.e., BrC + black carbon (BC)) (Zeng et al., 2020). Due to its absorption at $\mathrm{UV}$ wavelengths, $\mathrm{BrC}$ may also suppress photolysis rates of some chemical reactions, such as decreasing surface ozone concentrations in certain locations (Jo et al., 2016). A fraction of $\mathrm{BrC}$ chromophores are composed of nitro- or oxy-aromatic species (Desyaterik et al., 2013; Zhang et al., 2013), which are known toxins (Bandowe and Meusel, 2017; Tian et al., 2020), making measurements of $\mathrm{BrC}$ chromophores a useful tool for assessing aerosol health impacts from specific emissions (Verma et al., 2015; Gao et al., 2020a, b). Unfortunately, ambient observations of $\mathrm{BrC}$ have been sparse, limiting an assessment of its impacts and the refinement of model simulations.

\subsection{Methods of brown carbon measurement}

Methods to determine $\mathrm{BrC}$ in suspended aerosol particles can be challenging. $\mathrm{BrC}$ and $\mathrm{BC}$ are often co-emitted and must be distinguished by their unique properties, including (1) the wavelength dependence of their absorption, (2) volatility or (3) solubility.

\section{Brown carbon determined from wavelength dependence of absorption}

The strong wavelength dependence of $\mathrm{BrC}$ absorption allows it to be determined from total absorption measurements $(\mathrm{BC}+\mathrm{BrC})$ at multiple wavelengths in some cases. This requires the assumption that $\mathrm{BrC}$ does not absorb at mid-visible and longer wavelengths and that the absorption Angström exponent (AAE; absorption $\sim \lambda^{-\mathrm{AAE}}$ ) for $\mathrm{BC}$ is known and constant with wavelength. AAE for BC is commonly calculated by fitting the absorption measurement based on two wavelengths in the visible wavelength range, or it is simply assumed to be 1 . $\mathrm{BrC}$ absorption at shorter wavelengths is then found by difference from the extrapolated $\mathrm{BC} \mathrm{AAE}$ (Lack and Langridge, 2013; Mohr et al., 2013). This approach can be applied to any technique that measures total absorption or absorption aerosol optical depth (AAOD) at multiple wavelengths, including filter-based methods, photoacoustic spectroscopy and remote sensing, although what is measured as $\mathrm{BrC}$ is operationally defined by the measurement method. Filter-based absorption measurements have existed for some time (Lin et al., 1973) and may suffer from artifacts (Bond et al., 1999; Subramanian et al., 2007; Lack et al., 2008), although correction methods have been proposed (Weingartner et al., 2003; Virkkula, 2010; Olson et al., 2015). Photoacoustic absorption spectroscopy measures aerosol light absorption at near-ambient conditions by heating particles with a controlled light source and detecting the sound wave but is subject to interference by gaseous absorbers and sensitive to variations in temperature, pressure and relative humidity (Arnott et al., 1999; Langridge et al., 2013). Ground-based remote sensing can determine AAOD at multiple wavelengths (Aerosol Robotic Network, AERONET; Holben et al., 1998; Wang et al., 2016). For each of these approaches, the AAE fitting and extrapolation introduce uncertainties, including the calculation of AAE from only a few wavelengths (typically two) and the extrapolation to shorter wavelengths to determine a relatively small $\mathrm{BrC}$ contribution by difference. Studies that use an assumed AAE value introduce even greater uncertainty into the determination of $\mathrm{BrC}$, since a range of values for $\mathrm{BC}$ from 0.6-1.9 has been observed due to the coating effect (Bergstrom et al., 2007; Lack and Cappa, 2010; Lack et al., 2012; Bond et al., 2013; Lan et al., 2013; S. Liu et al., 2015; Li et al., 2016). Another BrC separation method employing an integrating sphere method introduced by Wonaschütz et al. (2009) first assumes all absorption at long wavelength $(660 \mathrm{~nm})$ is due solely to $\mathrm{BC}$, then an iterative technique is used to obtain $\mathrm{BrC}$ absorption based on calibration curves from simulated $\mathrm{BC}$ and $\mathrm{BrC}$ (carbon black and humic acid salt). The iteration can account for $\mathrm{BrC}$ absorption at longer wavelength, but there is difficulty in obtaining a calibration line for real ambient samples.

\section{Brown carbon determined from volatility}

$\mathrm{BrC}$ may also be determined from total absorption measurements of thermally denuded and ambient samples (Cappa et al., 2012; Lack et al., 2012). The low volatility of BC means that it remains after thermodenuding, and the difference between the total absorption and denuded absorption can be used to determined $\mathrm{BrC}$ absorption. Separating $\mathrm{BrC}$ and $\mathrm{BC}$ absorption using either thermodenuding or wavelength dependence can be complicated by morphological conditions, particularly the coating of $\mathrm{BrC}$ onto $\mathrm{BC}$ that results in increased absorption through lensing (Jacobson, 2001; Schnaiter et al., 2005; Bond and Bergstrom, 2006). BC absorption can be enhanced due to a lensing effect involving an absorbing core covered by a scattering or slightly absorbing shell (Bond and Bergstrom, 2006; Cappa et al., 2012; Lack and Langridge, 2013), but a simple core-shell structure may not accurately represent the actual particle morphology, leading to further uncertainty (Sedlacek III et al., 2012). Other studies suggest this enhancement is small in certain regions (Cappa et al., 2012, 2019). 


\section{Brown carbon determined from solubility}

Finally, BrC may be determined by extracting $\mathrm{BrC}$ chromophores in solvents to separate them from insoluble BC and measuring light absorption caused by the soluble organic chromophores (Hecobian et al., 2010). This is the only method to directly separate and quantify $\mathrm{BrC}$. A spectrophotometer with a UV-Vis light source and a longpath liquid waveguide capillary cell (LWCC) provides highspectral-resolution and high-sensitivity absorption measurements over a broad wavelength range through the use of long optical path lengths. Direct measurement of organic chromophores is also useful for studying the prevalence and fundamental properties of $\mathrm{BrC}$, such as the impact of aging on optical properties and the toxicity of chromophoric species. However, there are major limitations when using this method to determine aerosol optical effects since all particle size and morphological information is lost (Liu et al., 2013), and any $\mathrm{BrC}$ species insoluble in the selected solvents are not included. Other limitations include $\mathrm{pH}-\mathrm{dependent}$ absorption, blank stability, especially when using organic solvents, and artifacts which may be introduced by extensive dilution, resulting in changes in chemical properties of chromophores relative to those of the ambient aerosol (Hinrichs et al., 2016; Phillips et al., 2017; Teich et al., 2017).

Spectrophotometric measurements of chromophores in solutions can be utilized in both offline and online systems (Hecobian et al., 2010; J. Liu et al., 2013, 2015; Zhang et al., 2013). For offline systems, atmospheric particles are usually collected by filtration and then extracted with a solvent, such as water, methanol or acetonitrile (Chen and Bond, 2010), and absorptions of solvent and solute are quantified. Particle collection over a period of time onto a filter, followed by offline analyses at a later date, can lead to artifacts through filter sampling biases and changes during storage. Low time resolution and the resulting fewer data points can limit data interpretation. Among these weaknesses, poor time resolution is the most serious, especially when sampling fire plumes using a fast-moving aircraft. Online measurements can improve this, but these have only been used to measure water-soluble $\mathrm{BrC}$ due to the particle collection methods utilized. An online water-soluble $\mathrm{BrC}$ measuring system with a particle-into-liquid sampler (PILS)-liquid waveguide capillary cell (LWCC) has been used in previous ground-based studies (Hecobian et al., 2010; Washenfelder et al., 2015). Other systems can be used to collect the aerosol into water for subsequent $\mathrm{BrC}$ analysis, such as mist chambers (Cofer et al., 1985).

\section{Complications due to intermediate compounds}

Separating $\mathrm{BrC}$ and $\mathrm{BC}$ by the wavelength dependence of their absorption, their volatility or their solubility is complicated by the possible existence of compounds with intermediate properties of absorption, volatility or solubility. Some studies show evidence for the existence of intermediate $\mathrm{BrC}$ species, with properties between $\mathrm{BC}$ and $\mathrm{BrC}$ with a range of AAE values (Saleh et al., 2018). This intermediate $\mathrm{BrC}$ has been suggested to be an incompletely pyrolyzed precursor to $\mathrm{BC}$ that shows characteristics of both $\mathrm{BC}$ and BrC (Adler et al., 2019), much like what has been referred to as tar balls (Pósfai et al., 2004; Chakrabarty et al., 2010; Adachi et al., 2019) and consistent with the idea that carbonaceous lightabsorbing aerosol is comprised of a continuum of species from brown to black light absorbers (Cheng et al., 2021).

\subsection{This work}

Here, we assess three systems for measuring the light absorption of water-soluble $\mathrm{BrC}$ (WS $\mathrm{BrC}$ ) using either a mist chamber (MC) or PILS as the aerosol sampling system, followed by a LWCC and a spectrometer (MC-LWCC and PILS-LWCC). These instruments were deployed in three separate aircraft studies of wildfire smoke. MC sampling has been used in past NASA aircraft studies (Talbot et al., 1999; Dibb et al., 2003; Scheuer et al., 2003), whereas this paper describes the first deployment of the MC-LWCC system. Similarly, PILS-LWCC instruments have been developed and used in ground-based studies (Hecobian et al., 2010; Washenfelder et al., 2015), and PILS systems have been deployed on aircraft to measure aerosol composition (Sullivan et al., 2006, 2014, 2019), but this paper describes the first aircraft deployment of PILS-LWCC. BrC is reported in the form of light attenuation (unit of $\mathrm{Mm}^{-1}$ ) and not converted to a mass concentration because there is no constant $\mathrm{BC}$ mass absorption cross-section (MAC) value at a given wavelength as $\mathrm{BrC}$ is composed of multiple chromophores that change with emissions and atmospheric evolution.

\section{Experimental}

\subsection{Overview of aircraft studies and brown carbon instruments}

The Fire Influence on Regional to Global Environments Experiment - Air Quality (FIREX-AQ 2019; https://doi.org/10.5067/suborbital/firexaq2019/data001) and the Western Wildfire Experiment For Cloud Chemistry, Aerosol Absorption And Nitrogen (WE-CAN 2018; https://www.eol.ucar.edu/field_projects/we-can, last access: 18 September 2021) field studies investigated the emissions and evolution of gases and aerosols from wildfires and prescribed burning to better understand fire impacts on air quality and climate. FIREX-AQ included the NASA DC-8 research aircraft (average aircraft speed of $200 \mathrm{~m} \mathrm{~s}^{-1}$ ), which was deployed from Boise, ID, and Salina, KS, USA, during 22 July 2019-5 September 2019, and the NOAA Twin Otter research aircraft (average aircraft speed of $75 \mathrm{~m} \mathrm{~s}^{-1}$ ), which was deployed from Boise, ID, and Cedar City, UT, USA, during 3 August 2019-5 September 2019. WE-CAN 
included the NSF C-130 research aircraft (average aircraft speed of $100 \mathrm{~m} \mathrm{~s}^{-1}$ ), which was deployed from Boise, ID, USA, during 22 July 2018-14 September 2018. For each campaign, large wildfires in the western USA were identified, and flight plans included repeated plume intercepts to measure the smoke evolution.

The NASA DC-8, NOAA Twin Otter, and NSF C-130 payloads each included an instrument to measure the light absorption of WS BrC. These instruments employed similar approaches but were developed separately. Briefly, ambient air was sampled through an aircraft inlet and then collected in aqueous solution using either a MC or PILS. The visible and ultraviolet absorption by the aqueous solution was determined using a deuterium/halogen lamp, a LWCC and a grating spectrometer. All of the $\mathrm{BrC}$ measurements described in this work, including offline filter sample measurements, represent the water-soluble $\mathrm{BrC}$ absorption coefficient. Any intermediate species that exist between $\mathrm{BrC}$ and $\mathrm{BC}$ are likely to be insoluble in water, and we treat the water-soluble $\mathrm{BrC}$ measurements here as being solely attributable to $\mathrm{BrC}$. The three instruments are summarized in Table 1 and described in greater detail below.

\subsection{Online mist chamber measurements on the DC-8 aircraft during FIREX-AQ 2019}

A mist chamber-ion chromatograph (MC-IC) system has been deployed on the NASA DC-8 research aircraft in many previous missions for measurement of nitric acid and ionic particle species for all particles with sizes up to nominally $1 \mu \mathrm{m}$ (Scheuer et al., 2003). We used the existing MC as an aerosol collection method and added a spectrophotometer for online measurement of $\mathrm{BrC}$, without altering the existing MC-IC measurement capabilities. An instrument schematic is shown in Fig. 1. The mist chamber (or Cofer scrubber) has been extensively used to collect water-soluble gases or particles (Cofer et al., 1985; Cofer and Edahl, 1986; Spaulding et al., 2002). It must be operated vertically, with the top of the mist chamber connected to a vacuum pump. Sample air flows in from the bottom and enters the mist chamber through a tube with a nozzle at the tube exit that is situated near the center of the mist chamber, and then air exits the chamber at the top. Within this air jet, created by the nozzle, is a capillary that extends to near the bottom of the mist chamber. The low pressure near the air jet draws water sitting in the bottom of the chamber up the capillary, which breaks up the water into many small droplets within the air jet. The droplets and jet create a fine and uniform mist throughout the chamber, which is maintained in the chamber by a hydrophobic Teflon filter at the top of the mist chamber that limits most of the water from leaving with the sample air that is continually being drawn through the chamber (Cofer et al., 1985). Droplets impact on this filter and the walls, keeping all internal surfaces wet and draining to the liquid reservoir at the bottom, where it is continuously recycled through the jet during the sample collection period. After the sample collection period, liquid is removed from the chamber and analyzed. For the $\mathrm{BrC}$ measurement, this involves transferring the liquid sample via a syringe pump with an associated multiport selection valve to a $2.5 \mathrm{~m}$ long liquid waveguide capillary cell (LWCC-3250; World Precision Instruments, Sarasota, FL, USA, internal volume of $0.625 \mathrm{~mL}$ ). The LWCC was coupled to a deuterium/halogen light source with spectral output from 200$2500 \mathrm{~nm}$ (DH-mini Light Source, Ocean Optics, Dunedin, FL, USA) and a spectrometer (FLAME-T-UV-VIS, Ocean Optics, Dunedin, FL, USA). Light absorption was measured and recorded between nominally 300 and $900 \mathrm{~nm}$. A particle filter with $0.22 \mu \mathrm{m}$ pore size (Polypropylene, Tisch Scientific, North Bend, OH, USA) was installed in front of the LWCC to prevent the long capillary from becoming clogged and to limit contributions of insoluble particles larger than $0.22 \mu \mathrm{m}$ to the liquid absorption measurement. During the FIREX-AQ study, the liquid particle filter was replaced and rinsed with water at the beginning of every flight. The LWCC system was connected to the MC through a single channel on a multiport selection valve downstream of the syringe pump. A portion of the MC liquid sample was analyzed with an IC, and the remaining liquid in the chamber was directed to the LWCC through this separate channel. In this configuration, it did not affect the performance of the preexisting IC system for water-soluble ion quantification. Since the particle collection with the mist chamber was operated in batch mode, two MCs with identical corresponding syringe pumps operated alternatively, one sampling while the other was offline and the liquid sample was undergoing analysis. For example, a typical sampling sequence was as follows. The first MC (MC1 in Fig. 1) was filled with $12 \mathrm{~mL}$ of water via the syringe pump, and then the valve before the vacuum pump switched to allow sampling of ambient air at $\sim 50$ SLPM in that chamber. After $150 \mathrm{~s}$ of sampling, this valve was switched to sample from MC2 which had been flushed and contained $12 \mathrm{~mL}$ of water in preparation for sample collection. Now offline, the syringe pump for MC1 withdrew $6 \mathrm{~mL}$ of water and directed $3 \mathrm{~mL}$ through the $2.5 \mathrm{~m} \mathrm{LWCC}$. Absorbance spectra were recorded when sample pumping was completed, meaning that the liquid tubing/filter (green path in Fig. 1) and the LWCC had been flushed by about three volumes prior to the absorption measurement, and the flow was stopped. After analysis and removal of any remaining sample liquid from the offline chamber, MC1 was then cleaned by flushing with $10 \mathrm{~mL}$ of water but with no air flow. MC1 was inactive until the start of the next sampling cycle of sampling. Once air sampling had begun by MC1, the liquid in MC2 was injected into the LWCC and IC, then MC2 was cleaned. Liquid sample lines were $0.76 \mathrm{~mm}$ i.d. peek tubing, and the volume between the MC and LWCC was $0.5 \mathrm{~mL}$. There was a $166 \mathrm{~s}$ total time lag between the beginning of the actual sampling and the time the light absorbance spectrum was recorded.

A reference spectrum of pure solvent (water) was generated at the beginning of every flight at every wavelength 
Table 1. Overview of BrC instruments deployed during WE-CAN 2018 and FIREX-AQ 2019.

\begin{tabular}{|c|c|c|c|}
\hline & MC-LWCC & CSU PILS-LWCC & NOAA PILS-LWCC \\
\hline Research institution & $\begin{array}{l}\text { University of New Hampshire } \\
\text { Georgia Institute of Technol- } \\
\text { ogy }\end{array}$ & Colorado State University & $\begin{array}{l}\text { NOAA Chemical Sciences } \\
\text { Laboratory }\end{array}$ \\
\hline Field campaign & FIREX-AQ 2019 & WE-CAN 2018 & FIREX-AQ 2019 \\
\hline Aircraft & NASA DC-8 & NSF C-130 & NOAA Twin Otter \\
\hline Aircraft altitude & $200-1000 \mathrm{hPa}$ & $430-1000 \mathrm{hPa}$ & $630-1000 \mathrm{hPa}$ \\
\hline Inlet pressure control & None & None & $620 \mathrm{hPa}$ \\
\hline Aerosol collection & $\begin{array}{l}\text { Mist chamber (Scheuer et al., } \\
\text { 2003) }\end{array}$ & Particle-into-liquid sampler & $\begin{array}{l}\text { Particle-into-liquid sampler } \\
\text { (PILS-4001, Brechtel) }\end{array}$ \\
\hline Liquid transfer & Two syringe pumps & $\begin{array}{l}\text { Syringe pumps and a peri- } \\
\text { staltic pump }\end{array}$ & Peristaltic pump \\
\hline Solvent & Water & Water & Water \\
\hline $\begin{array}{l}\text { Aerosol collection efficiency } \\
\text { and system dilution }\end{array}$ & $\begin{array}{l}\text { Standard addition of trifluo- } \\
\text { roacetic acid to determine } \\
\text { evaporative loss in mist cham- } \\
\text { ber }\end{array}$ & $\begin{array}{l}\text { Dilution ratio due to condensa- } \\
\text { tion was obtained from previ- } \\
\text { ous measurements }\end{array}$ & $\begin{array}{l}\text { Aerosol collection efficiency } \\
\text { of } 0.8 \text { for } D_{\mathrm{p}}<1 \mu \mathrm{m} \text { from cal- } \\
\text { ibration with aerosolized su- } \\
\text { crose particles post-campaign }\end{array}$ \\
\hline Removal of gas-phase VOCs & NA & $\begin{array}{l}\text { Parallel plate carbon filter de- } \\
\text { nuder }\end{array}$ & $\begin{array}{l}\text { Parallel plate carbon filter de- } \\
\text { nuder (DN-100, Sunset Labo- } \\
\text { ratory) }\end{array}$ \\
\hline Light source & $\begin{array}{l}\text { Deuterium and halogen lamps } \\
\text { (DH-mini, Ocean Optics) }\end{array}$ & $\begin{array}{l}\text { Deuterium and halogen lamps } \\
\text { (DH-mini, Ocean Optics) }\end{array}$ & $\begin{array}{l}\text { Deuterium and halogen lamps } \\
\text { (DH-mini, Ocean Optics) }\end{array}$ \\
\hline Liquid waveguide & $\begin{array}{l}2.5 \mathrm{~m} \\
\text { (LWCC-3250, World Precision } \\
\text { Inst.) }\end{array}$ & $\begin{array}{l}2.5 \mathrm{~m} \\
\text { (LWCC-3250, World Precision } \\
\text { Inst.) }\end{array}$ & $\begin{array}{l}2.5 \mathrm{~m} \\
\text { (LWCC-3250, World Precision } \\
\text { Inst.) }\end{array}$ \\
\hline Spectrometer & $\begin{array}{l}\text { Ocean Optics FLAME-T-UV- } \\
\text { VIS }\end{array}$ & $\begin{array}{l}\text { Ocean Optics FLAME-T-UV- } \\
\text { VIS }\end{array}$ & Ocean Optics QE Pro \\
\hline Spectral range & $300-700 \mathrm{~nm}$ & $300-700 \mathrm{~nm}$ & $309-682 \mathrm{~nm}$ \\
\hline Spectral resolution & $1.4 \mathrm{~nm}$ & $1.4 \mathrm{~nm}$ & $3.3 \mathrm{~nm}$ \\
\hline Zero measurement & NA & $\begin{array}{l}\text { Filtered air measured for } \\
10 \text { min manually twice per } \\
\text { flight }\end{array}$ & $\begin{array}{l}\text { Filtered air measured for } 6 \mathrm{~min} \\
\text { every } 1.5 \mathrm{~h}\end{array}$ \\
\hline $\begin{array}{l}\text { Detection limit }(3 \sigma) \text { at } \\
365 \mathrm{~nm}\end{array}$ & $1.53 \mathrm{Mm}^{-1}$ & $0.89 \mathrm{Mm}^{-1}$ & $0.03 \mathrm{Mm}^{-1}$ \\
\hline Uncertainty & $28 \%$ & $12 \%$ & $11 \%$ \\
\hline
\end{tabular}

$\left(I_{0}(\lambda)\right.$ in Eq. 1), and the light absorbance $\left(\log _{10}\left(I_{0}(\lambda) / I(\lambda)\right)\right)$ was quantified by the spectrometer over the full spectrum. The integration time of the spectrometer was usually less than $0.1 \mathrm{~s}$ to keep the intensity at $365 \mathrm{~nm}$ in the range of 25000 to 30000 counts (i.e., below saturation). An internal standard of known aqueous concentration of trifluoroacetic acid (7.5 ppbm TFA) was added to the water supplied to the $\mathrm{MC}$ to track any evaporative loss of water from the MC during sampling, which was monitored with the MC-IC system.
TFA did not interfere with the absorption measurement in the 300 to $700 \mathrm{~nm}$ wavelength range.

\subsection{Online PILS measurements on the NSF C-130 aircraft during WE-CAN 2018}

Unlike the mist chamber system, the PILS is run in a continuous sampling mode. The instrument operates by condensing water vapor onto particles with a saturated steam flow 


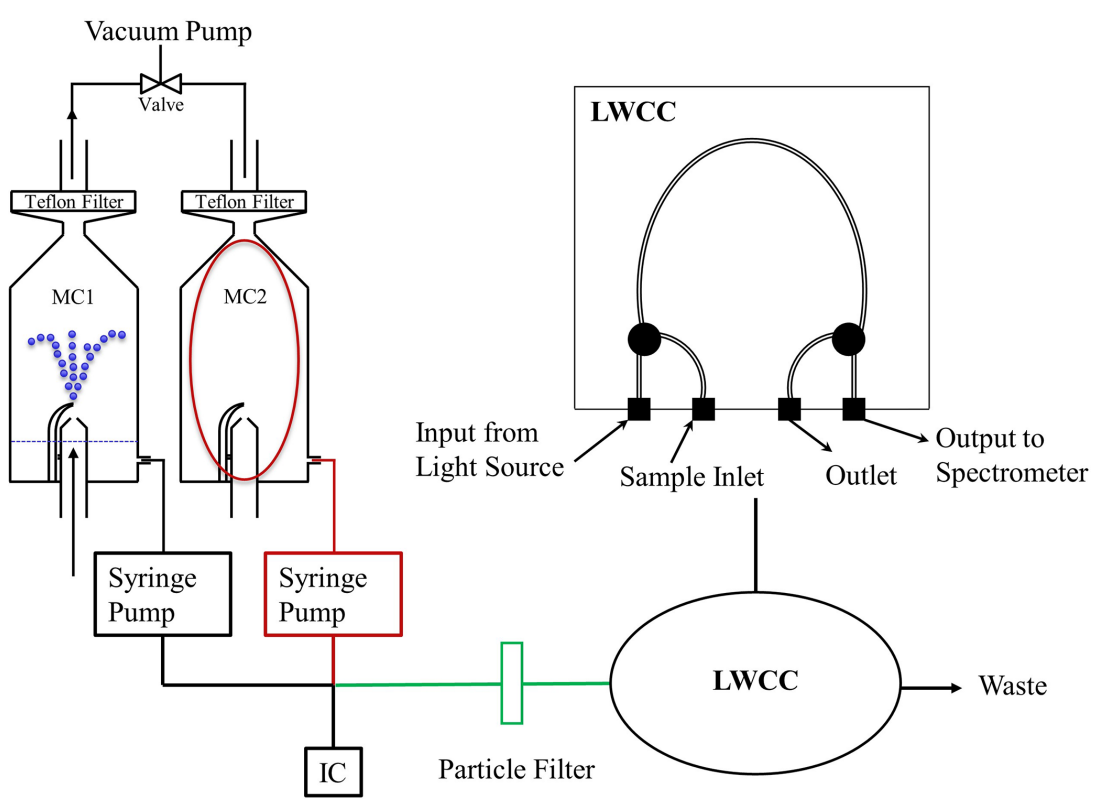

Figure 1. Flow diagram of the MC-LWCC instrument for WS BrC. Blue dots represent the mist generated in the scrubber. Red lines are the first hysteresis components described in Sect. 3.3, and green lines are the second components.

and then using a single jet inertial impactor to collect the droplets onto a vertical impaction plate that is continually washed with a constant diluent flow (Weber et al., 2001; Orsini et al., 2003). Compared to a mist chamber, the PILS uses smaller liquid volumes and a smaller sampling flow rate and produces a continuous liquid sample flow. The Colorado State University (CSU) PILS-LWCC system was similar to the one used in previous ground-based studies (Hecobian et al., 2010), and the schematic is shown in Fig. 2a. Ambient air was sampled with a submicron aerosol inlet (SMAI) (Craig et al., 2013a, b, 2014; Moharreri et al., 2014) and passed through a nonrotating micro-orifice uniform deposit impactor (MOUDI) with a $50 \%$ transmission efficiency at $1 \mu \mathrm{m}$ (aerodynamic diameter) at 1 atmosphere ambient pressure (Marple et al., 1991). The total airflow of the PILS was 15 SLPM (volumetric flow was controlled by a critical orifice). An activated carbon parallel plate denuder (Eatough et al., 1993) was placed upstream of the PILS to remove organic gases. The sample air then mixed with saturated water vapor (steam) in the growth chamber, and all particles in the sample air nominally larger than $40 \mathrm{~nm}$ grew to a few microns in size and were then collected by impaction. The impaction plate was continually washed with a pure water transport flow of $1.3 \mathrm{~mL} \mathrm{~min}^{-1}$ dictated by the needs of the total organic carbon analyzer (Sievers M9 Portable TOC analyzer; SUEZ Water Technologies \& Solutions, Trevose, PA, USA) that was placed after the LWCC to quantify watersoluble organic carbon (WSOC). The liquid sample obtained from the PILS was then passed through a blown-glass debubbler, resulting in a liquid sample free of air bubbles at a flow rate of $1.2 \mathrm{~mL} \mathrm{~min}^{-1}$, which was then filtered by a $0.2 \mu \mathrm{m}$ pore size PTFE liquid particle filter (Whatman plc, Maidstone, UK) to remove larger insoluble particles. The flow was then directed through a $2.5 \mathrm{~m}$ liquid waveguide capillary cell (LWCC-3250, World Precision Instruments, Sarasota, FL, USA) and TOC analyzer for near real-time measurement of WS BrC and WSOC, respectively. The LWCC was coupled to a deuterium/halogen light source (DH-mini Light Source, Ocean Optics, Dunedin, FL, USA) and spectrometer (FLAME-T-UV-VIS, Ocean Optics, Dunedin, FL, USA), the same model LWCC and spectrophotometer as used with the MC-LWCC and offline filter sampling system discussed below.

All liquid sample lines were $0.51 \mathrm{~mm}$ i.d. PEEK tubing. The liquid handling for the flows to and from the impactor used two pairs of syringe pumps with $1 \mathrm{~mL}$ syringes operating in handshaking mode. This minimized contamination was observed by peristaltic pumps in previous ground-based studies and provided more precise flow control for aircraft sampling with rapid changes in ambient pressure. One pair of syringe pumps delivered the transport flow to the top of the PILS impactor, and the other pair withdrew the sample out of the PILS and pushed it through the liquid filter and to the LWCC and TOC analyzer. A peristaltic pump handled other liquid flows to operate the PILS (see Fig. 2a). Using syringe pumps to move sample liquid to the LWCC has a major disadvantage because it alters the relationship between sample collection and analysis in each syringe stroke; the first liquid into the syringe is the last out (and last sample in is the first out), assuming minimal mixing in the syringe. This results in a roughly $1 \mathrm{~min}(50 \mathrm{~s})$ loss in sample time resolution (volume of syringe is $1 \mathrm{~mL}$ and flow rate $1.2 \mathrm{~mL} \mathrm{~min}^{-1}$ ). The 

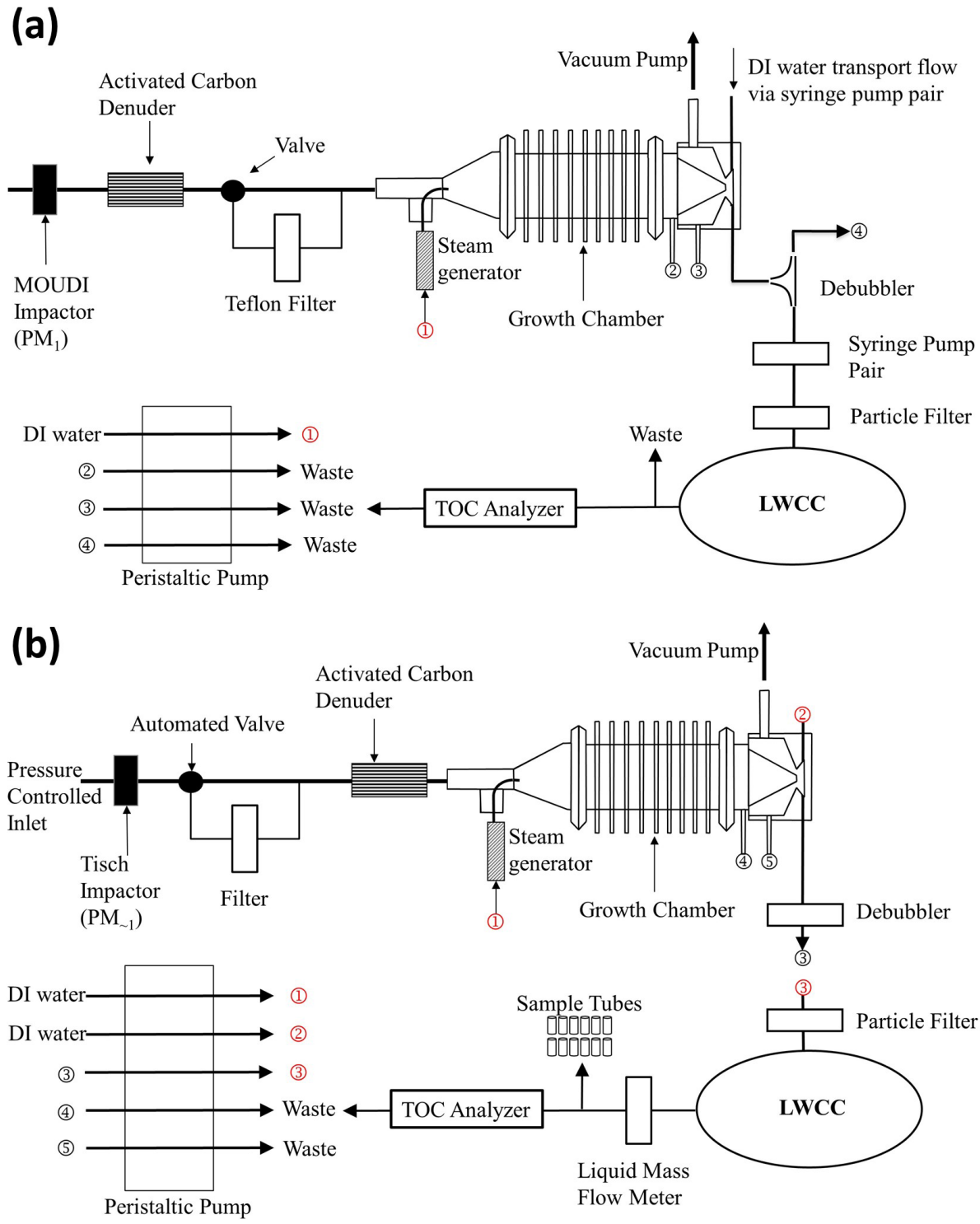

Figure 2. Flow diagrams of the (a) CSU PILS-LWCC and (b) NOAA PILS-LWCC instruments for WS BrC. For the CSU PILS-LWCC, a combination of syringe and peristaltic pumps was used for handling the liquid flows. For the NOAA PILS-LWCC, a peristaltic pump was used for all flows.

LWCC internal volume of $0.625 \mathrm{~mL}$ and liquid flow rate of $1.2 \mathrm{~mL} \mathrm{~min}^{-1}$ mean the light absorption measurement is also averaged over a $32 \mathrm{~s}$ interval. The absorbance spectrum was saved every $16 \mathrm{~s}$. Because of these effects, the time resolution of this method was roughly 1 min. Periodic background measurements were made by manually switching a valve upstream of the PILS to direct sample air through a Teflon filter for $10 \mathrm{~min}$. A dilution factor of 1.33 was used to account for dilution from steam condensation.

\subsection{Online PILS measurements by NOAA on the NOAA Twin Otter aircraft during FIREX-AQ 2019}

The NOAA PILS-LWCC instrument was developed separately but followed the approach first described in Hecobian et al. (2010) and is similar to the CSU PILS-LWCC system. The key differences of the NOAA PILS-LWCC system included (1) a pressure-controlled aerosol inlet with constant PILS gas flow, (2) an automated valve and aerosol filter to record aerosol-free background measurements in flight and (3) a five-channel peristaltic pump for all liquid flow transfer, including the sample lines in and out of the PILS impactor. These details and the full system are described below. The schematic of the NOAA PILS-LWCC is shown in Fig. $2 b$. 
During FIREX-AQ, the NOAA PILS-LWCC sampled from a forward-facing, near-isokinetic inlet (Schwarz et al., 2006; Perring et al., 2013) on the NOAA Twin Otter aircraft. The inlet flow was actively pressure-controlled at $620 \mathrm{hPa}$ using a flow restriction, pressure controller and scroll pump. The total inlet sample flow of 8.13 SLPM passed through an impactor (TE296, Tisch Environmental, Cleves, OH, USA) with a measured $50 \%$ cut point at $0.95 \mu \mathrm{m}$ and was then distributed to the aerosol instruments on board the NOAA Twin Otter. The PILS-LWCC sampled the incoming aerosol flow through an automated valve (MDM-060DT; Hanbay Laboratory Automation, Pointe Claire, QC, CAN) with filter (116IL; Headline Filters Limited, Aylesford, Kent, UK) for periodic, automated measurements of the aerosol-free background that were performed for 6 min every $1.5 \mathrm{~h}$. A parallel-plate carbon filter denuder (DN-100; Sunset Laboratory, Tigard, OR, USA) removed gas-phase volatile organic compounds (VOCs). Pressure and temperature of the flow were recorded at $1 \mathrm{~Hz}$.

The PILS (PILS 4001, Brechtel Manufacturing Inc., Hayward, CA, USA) collected aerosol in solution using a steam generator, droplet impactor and five-channel peristaltic pump, with an average liquid output flow from the impactor of $1.53 \mathrm{~mL} \mathrm{~min}^{-1}$. The sample air flow into the PILS was maintained at a constant 6.0 SLPM using a $1.35 \mathrm{~mm}$ diameter critical orifice (Lenox Laser, Glen Arm, MD, USA) between the PILS and the scroll pump. The pressure-controlled inlet and constant gas flow had two advantages for the PILSLWCC: (1) the steam temperature within the PILS varies with pressure according to the Clausius-Clapeyron equation, and maintaining a constant gas pressure within the PILS allowed more stable behavior and better characterization of the PILS collection efficiency; (2) the liquid flow from the peristaltic pumps was found to vary with the system pressure, and maintaining constant upstream pressure improved the system stability and accuracy. Bubbles were removed using a commercially available flow-through debubbler (Omnifit 006BT; Diba Industries, Inc., Danbury, CT; modified by Brechtel Manufacturing Inc), consisting of a porous PTFE membrane under vacuum.

Following the PILS, a particle filter with $0.2 \mu \mathrm{m}$ pore size (Puradisc 25 TF; GE Healthcare Life Sciences, Pittsburgh, PA, USA) removed insoluble components from the liquid sample stream before it entered the $2.5 \mathrm{~m}$ long LWCC, which is the same model used in the other instruments (LWCC3250, World Precision Instruments, Sarasota, FL, USA). Subsequently, $1.1 \mathrm{~mL} \mathrm{~min}^{-1}$ was sampled by a TOC analyzer (M9 Portable TOC analyzer; GE Analytical Instruments Inc., Boulder, CO, USA) for measurement of WSOC and the excess flow $\left(\sim 0.43 \mathrm{~mL} \mathrm{~min}^{-1}\right)$ was directed by an automated 14-port valve (C25Z; Vici Valco Instruments, Houston, TX, USA) to a series of 12 polypropylene sample tubes for offline analysis or to a waste container.

Similar to the CSU PILS-LWCC, the optical system consisted of a deuterium/halogen light source (DH-mini; Ocean
Optics Inc., Dunedin, FL, USA) coupled to the LWCC; however in this case, the exiting light was coupled to a $101 \mathrm{~mm}$ focal length symmetrical cross Czerny-Turner spectrometer with a 18-bit back-thinned $1024 \times 58$ pixel CCD array detector cooled to $-5^{\circ} \mathrm{C}$ (QE Pro; Ocean Optics Inc., Dunedin, FL, USA). The spectrometer contained a 600 groove $\mathrm{mm}^{-1}$ grating ( $300 \mathrm{~nm}$ blaze wavelength) rotated to give a useful spectral range from 309 to $682 \mathrm{~nm}$. The entrance slit was $200 \mu \mathrm{m}$ wide $\times 1000 \mu \mathrm{m}$ tall and was illuminated by a fiber bundle containing a linear array of $200 \mu \mathrm{m}$ diameter UV-Vis fibers. A total of 50 spectra with $0.02 \mathrm{~s}$ integration time were averaged to $1 \mathrm{~Hz}$ and saved. Following the field campaign, the collection efficiency of the PILS system at $620 \mathrm{hPa}$ was measured using atomized sucrose aerosol, and the $\mathrm{BrC}$ absorption and WSOC concentrations were subsequently corrected by a factor of 1.25 . Since this system used a peristaltic pump (in contrast to the syringe pump of the CSU PILS-LWCC system) to move liquid sample from the PILS to the LWCC, the time resolution should be improved. At a liquid sample flow rate of $1.53 \mathrm{~mL} \mathrm{~min}^{-1}$ through the LWCC of internal volume 0.625 , the maximum possible time resolution would be $25 \mathrm{~s}$, assuming no other interferences. The observed time resolution is $60 \mathrm{~s}$, likely due to sample mixing at the PILS impaction plate, liquid fittings and other instrument components.

\subsection{Offline measurements from filter samples on the DC-8 aircraft during FIREX-AQ 2019}

Filters were also collected as part of the FIREX-AQ NASA DC-8 measurement suite and $\mathrm{BrC}$ was determined offline with the same analytical method used in previous missions (i.e., NASA SEAC ${ }^{4}$ RS, DC3, and ATom, which are described in detail elsewhere (J. Liu et al., 2014, 2015; Zhang et al., 2017; Zeng et al., 2020)). Atmospheric particles with aerodynamic diameters less than nominally $4.1 \mu \mathrm{m}$ were collected onto $90 \mathrm{~mm}$ diameter Teflon filters with $1 \mu \mathrm{m}$ pore size (MilliporeSigma, Burlington, MA, USA) (McNaughton et al., 2007). During plume sampling, each filter sample was timed to (as best as possible) coincide with a transect through a single smoke plume. During other periods, sampling times were generally $5 \mathrm{~min}$ or less when sampling at altitudes below $3 \mathrm{~km}$ and increased to a maximum of $15 \mathrm{~min}$ for higher altitudes. Subsequently, the filters were extracted first into $15 \mathrm{~mL}$ of water via $30 \mathrm{~min}$ of sonication, and then using a syringe pump, extracts were filtered and injected into a $2.5 \mathrm{~m}$ LWCC (LWCC-3250, World Precision Instruments, Sarasota, FL, USA), coupled with the same light source and spectrometer (USB-4000, similar to FLAME-T-UV-VIS, Ocean Optics, Dunedin, FL, USA). The air filters were dried passively and then extracted again in $15 \mathrm{~mL}$ of methanol, and this extraction liquid was filtered and injected with the syringe pump into the LWCC. Only the water extracts are discussed here for comparison to the MC-LWCC. The same type of $0.22 \mu \mathrm{m}$ pore size particle filter as the online sys- 
tem was installed in front of the LWCC to filter out insoluble particles for both the water and methanol extracts, and the particle filter was changed every 5 to 20 samples depending on the sample concentration. Overall, the spectrometer was operated in the same way as the online MC system. Some samples collected in thick fire plumes were diluted to prevent saturation of the raw absorbance signal. Due to high organic concentrations in the filter extracts, the waveguide required periodic cleaning. Contamination was observed as the signal intensity for pure solvent, $I_{0}(\lambda)$, decreasing as contaminates accumulated in the waveguide. Flushing the waveguide with a large volume $(50 \mathrm{~mL})$ of water was generally sufficient to clean it, but occasionally a stronger cleanser $(10 \%$ of Contrad-NF, Decon Labs, King of Prussia, PA, USA) was used, as recommended by the manufacturer.

\subsection{Calculation of light absorption for PILS-LWCC, MC-LWCC and filter samples}

Light absorption by the liquid in the LWCC is described by Beer's law:

$$
\begin{aligned}
\operatorname{Abs}_{\text {solution }}(\lambda) & =c_{\text {solution }} \cdot \sigma_{\text {solution }}(\lambda) \\
& =\frac{1}{l} \cdot \log _{10}\left(\frac{I_{0}(\lambda)}{I(\lambda)}\right),
\end{aligned}
$$

where $\operatorname{Abs}_{\text {solution }}(\lambda)$ is the absorption of the solution, $c$ is concentration, $\sigma_{\text {solution }}(\lambda)$ is the mass absorption efficiency, $l$ is the LWCC cell length, $I_{0}(\lambda)$ is light intensity in the absence of the absorber, which is the spectrum of pure water, and $I(\lambda)$ is light intensity with the absorber present. This can be converted to an absorption coefficient for the aerosol:

$\operatorname{Abs}_{\text {aerosol }}(\lambda)=\frac{V_{\text {solution }} \times \log _{10}\left(\frac{I_{0}(\lambda)}{I(\lambda)}\right)}{V_{\text {air }} \times l} \times \ln (10)$.

For online PILS-LWCC measurements, $V_{\text {solution }}$ is the liquid sample flow rate, and $V_{\text {air }}$ is the air flow rate. For the MCLWCC and offline filter measurements, $V_{\text {solution }}$ is the liquid sample volume for extraction, and $V_{\text {air }}$ is the sampled volume of air. The light absorption determined from Eq. (2) is not directly equivalent to the ambient particle light absorption coefficient due to Mie effects. To determine the absorption that would be observed in the particle phase, the solution-phase absorption must be corrected as described previously (Liu et al., 2013; Zeng et al., 2020). The correction can be calculated from the imaginary part $(k)$ of the aerosol complex refractive index, $m=n+i k$, and the measured size distribution. In this work, we report only the light absorption from water-soluble chromophores, calculated from Eq. (2).

The absorption coefficient at $365 \mathrm{~nm}\left(\mathrm{Abs}_{365 \mathrm{~nm}}\right)$ is used to represent WS $\mathrm{BrC}$ absorption in the analysis and figures and is determined by averaging from 360 to $370 \mathrm{~nm}$. Abs $675 \mathrm{~nm}$ (670-680 $\mathrm{nm}$ average) or Abs700 $\mathrm{nm}$ (695-705 nm average) is used as a baseline to monitor any air bubbles or insoluble BC passing through the liquid particle filter (pore-size: $0.22 \mu \mathrm{m}$ for MC and filter; $0.2 \mu \mathrm{m}$ for PILS), with the assumption $\mathrm{BrC}$ does not absorb light in these wavelength ranges. All absorption coefficient data have been blank-corrected by water blanks for MC-LWCC and field blanks for PILS-LWCC by switching the upstream valve. Data from the MC-LWCC and PILS-LWCC instruments were time-corrected due to delays in the liquid flow system between sampling and analysis.

\subsection{Other measurements}

Carbon monoxide ( $\mathrm{CO}$ ) is emitted by biomass burning and is relatively chemically inert. It is often used as a marker for smoke and as a tracer for determining plume dilution. For the NASA DC-8 during FIREX-AQ, CO was measured with a diode laser spectrometer method (Differential Absorption Carbon Monoxide Measurements; DACOM; Warner et al., 2010). For the NSF C-130 during WE-CAN, CO was measured by a quantum cascade laser instrument (CS-108 miniQCL, Aerodyne Research Inc., Billerica, MA, USA). For the NOAA Twin Otter during FIREX-AQ, CO was measured by cavity ring-down spectroscopy (G2401-m; Picarro Inc., Santa Clara, CA, USA; Crosson, 2008; Karion et al., 2013).

Refractory black carbon (rBC, or just BC) was measured by a single particle soot photometer (SP2) on the DC-8 and the C-130 aircraft. The SP2 measures the incandescent signal generated from single particles heated by a laser source, which is proportional to their mass (Schwarz et al., 2008). The SP2 measured rBC particles with mass equivalent diameters between $\sim 90-550 \mathrm{~nm}$ on the DC-8 during FIREXAQ and $\sim 90-500 \mathrm{~nm}$ on the C-130 during WE-CAN. Higher frequency $\mathrm{CO}$ and $\mathrm{BC}$ data were merged to the MC-LWCC, PILS-LWCC or filter collection times as needed. BC was not measured on the NOAA Twin Otter.

\section{Results and discussion}

\subsection{Brown carbon measurements in smoke plumes}

Example flight tracks downwind of wildfires are shown in Fig. 3 for the three aircraft. Each of these flights sampled a single fire complex, with initial transects close to the source, followed by a pattern of downwind transects ideally perpendicular to the dominant wind direction. This type of sampling was repeated for numerous fires throughout each field study. The corresponding time series of Abs $365 \mathrm{~nm}$ and baseline Abs700 nm (Abs675 nm for NOAA PILS-LWCC) for these flights are shown in Fig. 4. The $1 \mathrm{~Hz} \mathrm{CO}$ concentrations are plotted to identify when the aircraft was in smoke and indicate smoke concentrations. The peak $\mathrm{CO}$ values decreased downwind as the plumes dispersed and diluted with cleaner background air as they advected away from the fire.

For these methods, in general, Abs $365 \mathrm{~nm}$ has a similar trend with $\mathrm{CO}$, but there are discrepancies. For the NASA 

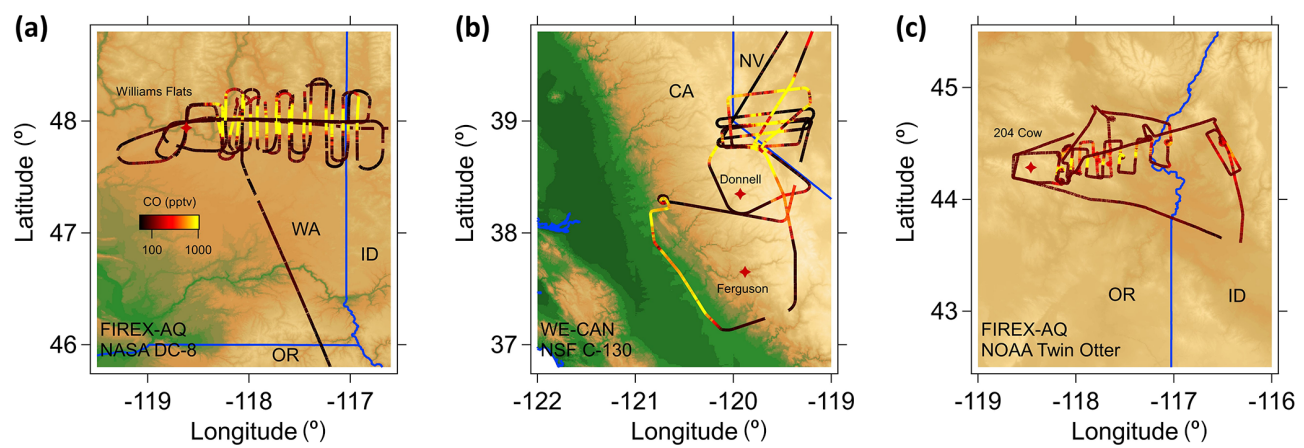

Figure 3. Examples of flight tracks for measurements made near and downwind of fires in the western USA for (a) the NASA DC-8 on 7 August 2019 in FIREX-AQ (MC-LWCC); (b) the NSF C-130 on 6 August 2018 in WE-CAN (CSU PILS-LWCC); and (c) the NOAA Twin Otter on 24 August 2019 in FIREX-AQ (NOAA PILS-LWCC). Each flight is color-coded by the CO mixing ratio. Fires are labeled with red stars.

DC-8 sampling during FIREX-AQ, the typical transit time through the plume was $\sim 3 \mathrm{~min}$, and the MC-LWCC sample time was $2.5 \mathrm{~min}$; thus the sampling frequency with this instrument was not sufficient to resolve structure within the plume during one transect. In contrast, the PILS-LWCC on the NSF C-130 and NOAA Twin Otter provided better time resolution. The average time for both the NSF C-130 and NOAA Twin Otter to transit a plume was $\sim 4$ min since their air speeds were lower than the DC-8. The data for all three systems show an increase in baseline $\left(\mathrm{Abs}_{700 \mathrm{~nm}}\right.$ or $\operatorname{Abs}_{675} \mathrm{~nm}$ ) within the plumes, and there is evidence of hysteresis in the $\mathrm{BrC}$ measurements. Both of these issues are discussed next.

\subsection{Baseline drift correction using long-wavelength absorption}

The accuracy of $\operatorname{Abs}(\lambda)$ calculated from Eq. (2) may be limited by drift in $I(\lambda)$. Potential sources of drift in $I(\lambda)$ include air bubbles in the LWCC, variable levels of insoluble BC that passed through the particle filter or changes in the light source intensity. Measured absorption at visible wavelengths can be used as a correction for air bubbles or insoluble BC in the LWCC. The presence of insoluble BC has been reported by Phillips and Smith (2017) for methanol extracts. They observed that the long-wavelength absorption decreased when filtering the liquid extract with smaller pore size particle filters. We use $\mathrm{Abs}_{675 \mathrm{~nm}}$ or $\mathrm{Abs}_{700 \mathrm{~nm}}$ for corrections here. This requires the assumption that WS $\mathrm{BrC}$ does not absorb at 675 or $700 \mathrm{~nm}$.

MC-LWCC. Figure 4a shows that $\mathrm{Abs}_{365} \mathrm{~nm}$ is correlated with $\mathrm{CO}$, with some differences. Abs $700 \mathrm{~nm}$ is generally less than $\sim 0.5 \mathrm{Mm}^{-1}$ when sampling background air but increases with $A_{b s} 365 \mathrm{~nm}$ in smoke plumes. Air bubbles or small insoluble black carbon particles that pass through the particle filter may lead to elevation of Abs700 nm as well as $\mathrm{Abs}_{365 \mathrm{~nm}}$. The scatter plot between $\mathrm{Abs}_{365 \mathrm{~nm}}$ and $\mathrm{Abs}_{700 \mathrm{~nm}}$ for all samples is shown in Fig. 5a. There are two groups of data. Red data points are typical $\mathrm{BrC}$ measurements that have high absorption at short wavelengths but insignificant absorption at long wavelengths, and $\mathrm{Abs}_{700 \mathrm{~nm}}$ is possibly due to the penetration of small $\mathrm{BC}$ particles through the liquid filter. Blue data points are interpreted to be small air bubbles in the sample liquid that were introduced during the syringe pump valve switching or due to leaks at liquid sample-line joints. The result is an upward shift of the complete absorption spectrum, which is consistent with a regression slope between $\mathrm{Abs}_{365 \mathrm{~nm}}$ and $\mathrm{Abs}_{700 \mathrm{~nm}}$ of approximately 1, and this error can be corrected by subtracting $A_{b s} 700 \mathrm{~nm}$ from $A b s(\lambda)$.

In most cases, however, the presence of $\mathrm{Abs}_{700 \mathrm{~nm}}$ is likely due to a fraction of $\mathrm{BC}$, which absorbs light at higher wavelengths (e.g., $700 \mathrm{~nm}$ ), that passed through the $0.22 \mu \mathrm{m}$ particle filter. Abs $700 \mathrm{~nm}$ is found to have a good correlation (Fig. 5e, $R^{2}=0.65$ ) with $\mathrm{BC}$ mass concentration, consistent with $\mathrm{BC}$ as a potential contributor of long wavelength absorption. These data suggest the MC-LWCC is at least somewhat effective at the collection of insoluble species into water.

Filters. In contrast to the MC system, when using a filter as the particle collection method, Abs $700 \mathrm{~nm}$ does not have any correlation with $\mathrm{Abs}_{365 \mathrm{~nm}}$, and the magnitude of $\mathrm{Abs}_{700 \mathrm{~nm}}$ is much smaller compared to that for the MC. The random interference at $\mathrm{Abs}_{700 \mathrm{~nm}}$ is not likely due to $\mathrm{BC}$ as $\mathrm{Abs}_{700 \mathrm{~nm}}$ is independent of the $\mathrm{BC}$ mass concentration, as shown in Fig. 5f. The filter collects insoluble particles, but apparently the water extraction process does not efficiently move these particles from the filter to the extraction water in comparison to the MC-LWCC.

CSU and NOAA PILS-LWCC. A slight but much smaller increase in the light absorption at high wavelengths is seen in the CSU (Fig. 4b) and NOAA PILS-LWCC data (Fig. 4c). Similar scatter plots, Fig. $5 \mathrm{c}$ and d, were made for data from the CSU PILS-LWCC and the NOAA PILS-LWCC, where the data were classified by flight using different colors. For the CSU PILS-LWCC, the slope of Abs $365 \mathrm{~nm}$ to Abs $700 \mathrm{~nm}$ varies between flights, whereas for the NOAA PILS-LWCC a 

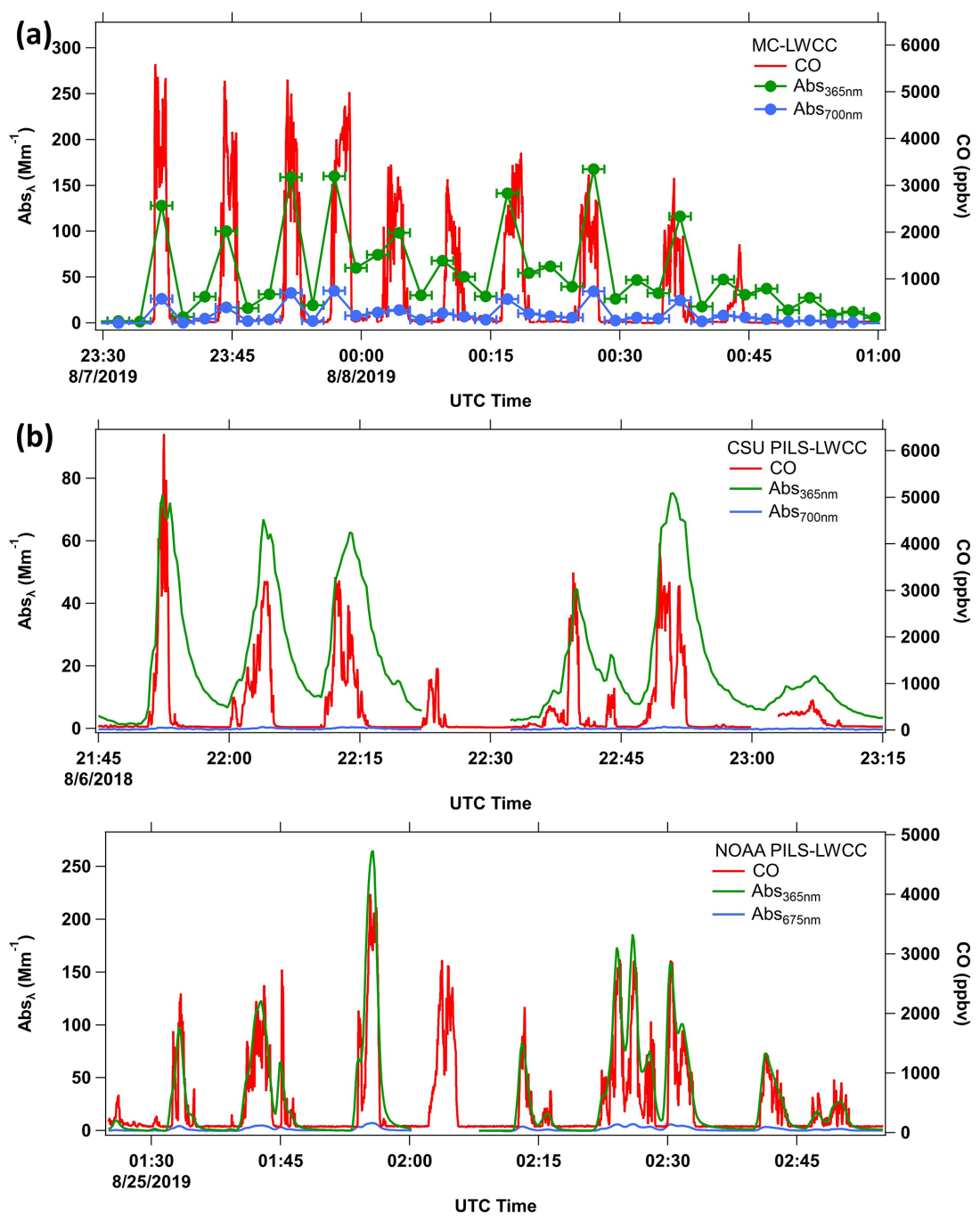

Figure 4. Example data from sampling in smoke plumes by MC-LWCC and PILS-LWCC (CSU and NOAA) systems for the flights shown in Fig. 3. Time series of $\mathrm{Abs}_{365 \mathrm{~nm}}$ (green), Abs700 nm or Abs $675 \mathrm{~nm}$ (blue) and CO (red) for the (a) FIREX-AQ NASA DC-8 flight on 7 August 2019, (b) WE-CAN NSF C-130 flight on 6 August 2018 and (c) FIREX-AQ NOAA Twin Otter flight on 24 August 2019. The sampling frequencies were (a) MC-LWCC, $2.5 \mathrm{~min}$; (b) CSU PILS-LWCC, $16 \mathrm{~s}$; (c) NOAA PILS-LWCC, $10 \mathrm{~s}$; and CO, $1 \mathrm{~s}$. Horizontal error bars in (a) represent the MC sampling interval.

similar relationship was seen for different flights. Comparing the CSU PILS-LWCC Abs $700 \mathrm{~nm}$ light absorption in Fig. 5g shows in most flights some relationship to BC or no relationship for a few flights. (A similar plot is not included for the NOAA PILS since no BC data were available.) The results suggest that some BC contributed to the PILS-LWCC measurement, but it was minor compared to the MC-LWCC (note the difference in axis scales). Previous studies have indicated that the PILS is not a good collector for water-insoluble species (Peltier et al., 2007). Since this analysis suggests it is largely due to some fraction of $\mathrm{BC}$ being included in the $\mathrm{BrC}$ measurement, this $\mathrm{BC}$ interference can be removed.

Baseline correction. $\operatorname{Abs}(\lambda)$ can be corrected for absorption by insoluble $\mathrm{BC}$ by assuming that $\mathrm{AAE}_{\mathrm{BC}}=1$ and $\mathrm{Abs}_{700 \mathrm{~nm}}$ is due to $\mathrm{BC}$ with no contribution from $\mathrm{BrC}$. These are the same assumptions that other optical instruments use to infer $\mathrm{BrC}$ from total light absorption, as described in the Introduction. With the assumption that $\mathrm{Abs}_{700 \mathrm{~nm}}$ is solely due to $\mathrm{BC}, \mathrm{Abs}_{365 \mathrm{~nm}}$ due to $\mathrm{BC}$ can be estimated to be equal to $(365 / 700)^{-1} \times \mathrm{Abs}_{700 \mathrm{~nm}}$. According to the slope of the red line in Fig. 5a, BC contributes to about onethird of Abs $365 \mathrm{~nm}$ measured with the MC. Alternatively, one can simply subtract the measured absorption at all wavelengths, including $\left(\mathrm{Abs}_{365 \mathrm{~nm}}\right)$ by $\mathrm{Abs}_{700 \mathrm{~nm}}(\mathrm{BrC}$, or corrected $\left.A_{b s} 365 \mathrm{~nm}=A_{b s} 365 \mathrm{~nm}-\mathrm{Abs}_{700 \mathrm{~nm}}\right)$. This simplified method results in $25 \%$ overestimation of $\mathrm{BrC}$ for the $\mathrm{MC}$ data compared to estimating the contribution of $\mathrm{BC}$ as a function of wavelength $(\mathrm{BC} \mathrm{AAE}=1)$. Therefore, in the following analysis for the MC-LWCC system, WS BrC was calculated by $\mathrm{WS} \mathrm{BrC}=\mathrm{Abs}_{365 \mathrm{~nm}}-(365 / 700)^{-1} \times \mathrm{Abs}_{700 \mathrm{~nm}}$. 

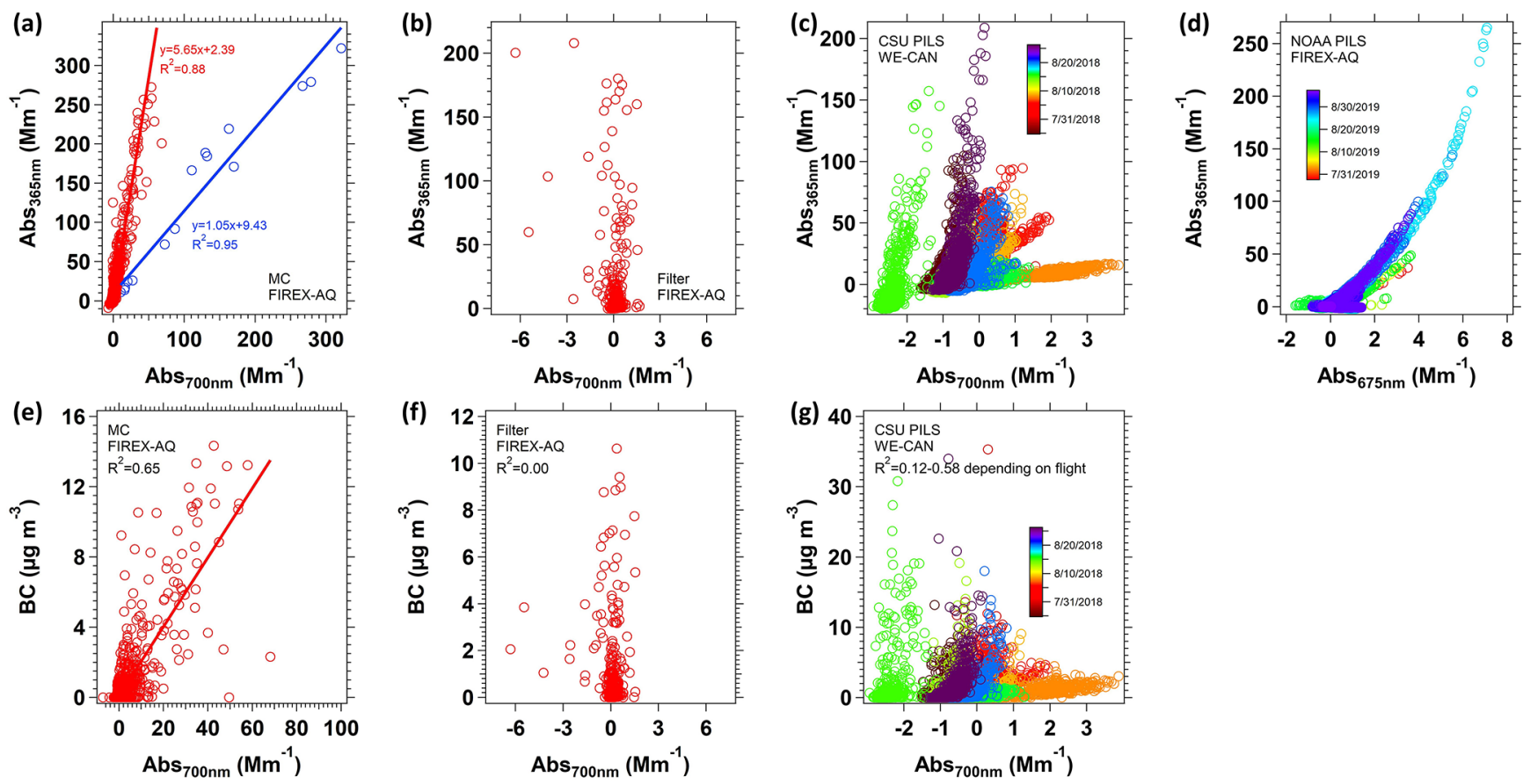

Figure 5. Scatter plots between $\mathrm{Abs}_{365 \mathrm{~nm}}$ and baseline (Abs $700 \mathrm{~nm}$; Abs $675 \mathrm{~nm}$ for NOAA PILS) with (a) MC, (b) filter, (c) CSU PILS and (d) NOAA PILS. The corresponding scatter plots between Abs700nm and BC are shown in (e)-(g). For the (a) MC-LWCC system, two groups of data are classified visually and fit with an orthogonal distance regression. Red data are the baseline drift due to BC passing the particle filter, and blue data are because of small air bubbles in the LWCC. For PILS-LWCC (c, d), data are color-coded by sampling date.

For the CSU PILS-LWCC, the overestimation is between $2 \%$ and $5 \%$ as BC is not as efficiently collected and transported to the LWCC. Thus, in the following, only the simplified method is used to correct for $\mathrm{BC}$ interference; that is, $\mathrm{CSU}$ $\mathrm{WS} \mathrm{BrC}=\mathrm{Abs}_{365 \mathrm{~nm}}-\mathrm{Abs}_{700 \mathrm{~nm}}$. The same approach was used for the filter data. No correction for BC in the NOAA PILS data is made because of an observed slow baseline drift for 365 and $675 \mathrm{~nm}$ absorption, possibly caused by independent drifts in the output of the deuterium lamp ( 200$400 \mathrm{~nm})$ and halogen lamp ( 400-1600 nm) within the DHmini light source. In any case, as noted above, the correction would be small $(<5 \%)$.

\subsection{Hysteresis}

An effect of retention of liquid on the internal wetted components (Gomes et al., 1993) or within dead volumes (i.e., poorly flushed volumes within fittings or components) in the instrument is an observed hysteresis, which appears as a tail or asymmetry in measurement peaks toward larger times. As seen in Fig. 4, WS BrC ( $\left.\mathrm{Abs}_{365} \mathrm{~nm}\right)$ demonstrates hysteresis when the aircraft exited a smoke plume for both the MC-LWCC and PILS-LWCC systems, whereas the CO mixing ratio decreases sharply (i.e., any hysteresis associated with the $\mathrm{CO}$ measurement is much less). The hysteresis in WS $\mathrm{BrC}$ results in it being overestimated when the aircraft moves out of a polluted region to a cleaner environment due to high residual concentrations from the previous run. Conversely, when moving from a region of low to high concentration, such as entering the smoke plume, cleaner sample liquid from the previous air mass sampled can dilute the current measurement, resulting in an underestimation of the $\mathrm{BrC}$ levels. The hysteresis effect is most obvious when the plume concentration changes significantly during a short period. These large hysteresis effects can to some extent be removed.

$M C$ - $L W C C$. For the $\mathrm{MC} \mathrm{BrC}$ measurement system, liquid remains in the $\mathrm{MC}$, syringe and liquid lines associated with a specific MC (red in Fig. 1; this whole group is referred to as just the MC) and in the common sample line and liquid filter shared by both MCs (green in Fig. 1) from the previous sample, although these common lines are flushed with sample prior to the measurement to minimize some of the latter hysteresis effect. Some fraction of the hysteresis can be removed by estimating its contribution based on comparison to a measurement that is not as affected by hysteresis, such as the $\mathrm{CO}$ measurement. The approach is based on two assumptions: (1) the volume fraction due to residues from the previous run does not change, making a constant hysteresis effect, no matter dilution or enrichment. (2) The WS BrC level is zero (or at least much lower compared to in the plume) when the $\mathrm{CO}$ concentration is at background concentrations; in this case we assume this occurs if $\mathrm{CO}<80 \mathrm{ppbv}$. For the $i$ th $\mathrm{MC}$ sample, we decompose the hysteresis into two components: 
(1) residue from a previous run of the same MC used to collect the currently analyzed sample, which, since there are two MCs running alternatively, is the sample from the $(i-2)$ th sample (i.e., red components in Fig. 1), and (2) residue from the tubing transporting the liquid from the MC to the LWCC (including the particle filter), which comes from the $(i-1)$ th (i.e., immediately preceding) sample (green components in Fig. 1). We pick time periods when the DC-8 was exiting fire plumes, in which case the observed WS BrC signals following the smoke plumes were ideally all due to contribution from the previous air mass sampled.

We assume the observed WS BrC absorption at the $i$ th sample is due to $a \%$ of the real WS BrC during the time period of the $i$ th sample, $b \%$ due to $(i-1)$ th sample from the tubing and $c \%$ due to $(i-2)$ th sample from the MC. Based on mass conservation, the relationship between the coefficients and absorption can be described by the following equations.

$$
a+b+c=100
$$

$$
\begin{aligned}
\operatorname{Abs}_{i, \text { observed }}= & a \% \times \mathrm{Abs}_{i, \text { real }} \\
& +b \% \times \mathrm{Abs}_{i-1, \text { observed }} \\
& +c \% \times \mathrm{Abs}_{i-2, \text { observed }}
\end{aligned}
$$

Rearranging Eq. (4),

$$
\begin{aligned}
a \% \times \operatorname{Abs}_{i, \text { real }}= & \operatorname{Abs}_{i, \text { observed }} \\
& -b \% \times \operatorname{Abs}_{i-1, \text { observed }} \\
& -c \% \times \operatorname{Abs}_{i-2, \text { observed }} .
\end{aligned}
$$

Using the sample immediately after the DC- 8 had just exited the plume and labeling the last WS $\mathrm{BrC}$ measurement within the plume as $\mathrm{Abs}_{0, \text { observed }}$, the series of measurements can be described as

$$
\begin{aligned}
a \% \times \operatorname{Abs}_{2, \text { real }}= & \mathrm{Abs}_{2, \text { observed }} \\
& -b \% \times \mathrm{Abs}_{1, \text { observed }} \\
& -c \% \times \mathrm{Abs}_{0, \text { observed }} \\
a \% \times \mathrm{Abs}_{3, \text { real }}= & \mathrm{Abs}_{3, \text { observed }} \\
& -b \% \times \mathrm{Abs}_{2, \text { observed }} \\
& -c \% \times \mathrm{Abs}_{1, \text { observed }} \\
a \% \times \mathrm{Abs}_{4, \text { real }}= & \mathrm{Abs}_{4, \text { observed }} \\
& -b \% \times \mathrm{Abs}_{3, \text { observed }} \\
& -c \% \times \mathrm{Abs}_{2, \text { observed }}
\end{aligned}
$$

..., etc.

The left side of the equations are zero due to the second assumption that WS $\mathrm{BrC}$ absorption is negligible outside the plume. These equations can be solved by least squares for an overdetermined system to obtain the coefficients, which, as noted, we assume are constant. For our MC setup we find $a=56 \pm 13, b=7 \pm 4$ and $c=37 \pm 12$ based on integrating the result from nine cases of plume exits, where the uncertainties are the standard deviations from multiple plume exit analyses. In other words, for one measurement of WS $\mathrm{BrC}$ absorption, about $56 \%$ of absorption is from the current $i$ th sample, and $7 \%$ from residue in the tubing due to $(i-1)$ th sample and $37 \%$ from MC residue due to $(i-2)$ th sample. The largest source is residue in the MC. Although $10 \mathrm{~mL}$ of water was used to clean the chamber, since there was no airflow during the cleaning, no mist was generated, and so the walls, nozzle and water-refluxing filter of the MC were not rinsed. As for hysteresis in the sample lines and LWCC, the length of the tubing between the MCs and LWCC was as short as possible (about $1 \mathrm{~m}$ long), but there was still $0.5 \mathrm{~mL}$ of liquid volume (with $0.76 \mathrm{~mm}$ i.d. tubing) for the instrument arrangement on the DC- 8 . The internal volume of the $2.5 \mathrm{~m} \mathrm{LWCC}$ was $0.625 \mathrm{~mL}$. In our setup, the maximum liquid available for the $\mathrm{BrC}$ measurement with the $\mathrm{LWCC}$ was $3 \mathrm{~mL}$ (the IC analysis required most of the $\mathrm{MC}$ liquid sample); thus based on the volume of the sample line and LWCC combined, these components were roughly flushed twice with the sample, and the third volume was used for the analysis (internal volume of tubing and LWCC was approximately $1 \mathrm{~mL}$ and volume of liquid sent through the system in each MC analysis was $3 \mathrm{~mL}$ ). Flushing with more sample (i.e., use more water in the $\mathrm{MC}$ ) would reduce the hysteresis, but the under-measurement of the peak $\mathrm{BrC}$ levels within the plume will remain, and it will also reduce the sensitivity of the overall $\mathrm{BrC}$ measurement if all other factors, such as sampling time, remain the same. From these analyses, the greatest improvement in the sampling system could be gained by minimizing hysteresis from residue in the $\mathrm{MC}$ from the previous sample.

Figure 6a shows the time series plot of WS $\mathrm{BrC}$ $\left(\operatorname{Abs}_{365 \mathrm{~nm}}-(365 / 700)^{-1} \times \mathrm{Abs}_{700 \mathrm{~nm}}\right)$ with CO before and after applying the hysteresis correction. This figure shows that corrected $\mathrm{WS} \mathrm{BrC}$ is higher within the plumes and lower outside the plumes and in better agreement with the $\mathrm{CO}$ trend, which is not affected by hysteresis. However, this method does not completely remove all hysteresis as some disagreement still exists. The uncertainties of the measurements also increased as the hysteresis is not a constant; the uncertainties of the three factors $a, b$ and $c$ are not insignificant, as assumed.

The effect of this correction can also be assessed through scatter plots of measured WS $\mathrm{BrC}$ and $\mathrm{CO}$ before and after the correction, as shown in Fig. 7a and b, respectively. A better correlation is observed when the hysteresis correction is applied; $R^{2}$ increases from 0.75 to 0.86 .

CSU and NOAA PILS-LWCC. A similar hysteresis of WS $\mathrm{BrC}$ is seen in the continuously flowing liquid system of the CSU PILS-LWCC relative to the CO data in Fig. 4b. Here we attempt to remove some of this effect by applying a similar analysis method used for the MC using the raw higher time resolution $\mathrm{BrC}$ data. Unlike the dual $\mathrm{MC}$ system, the hysteresis could occur from hang-up of liquid in the internal wetted components encompassing the PILS impaction plate to the LWCC, along with the mixing caused by using a sy- 

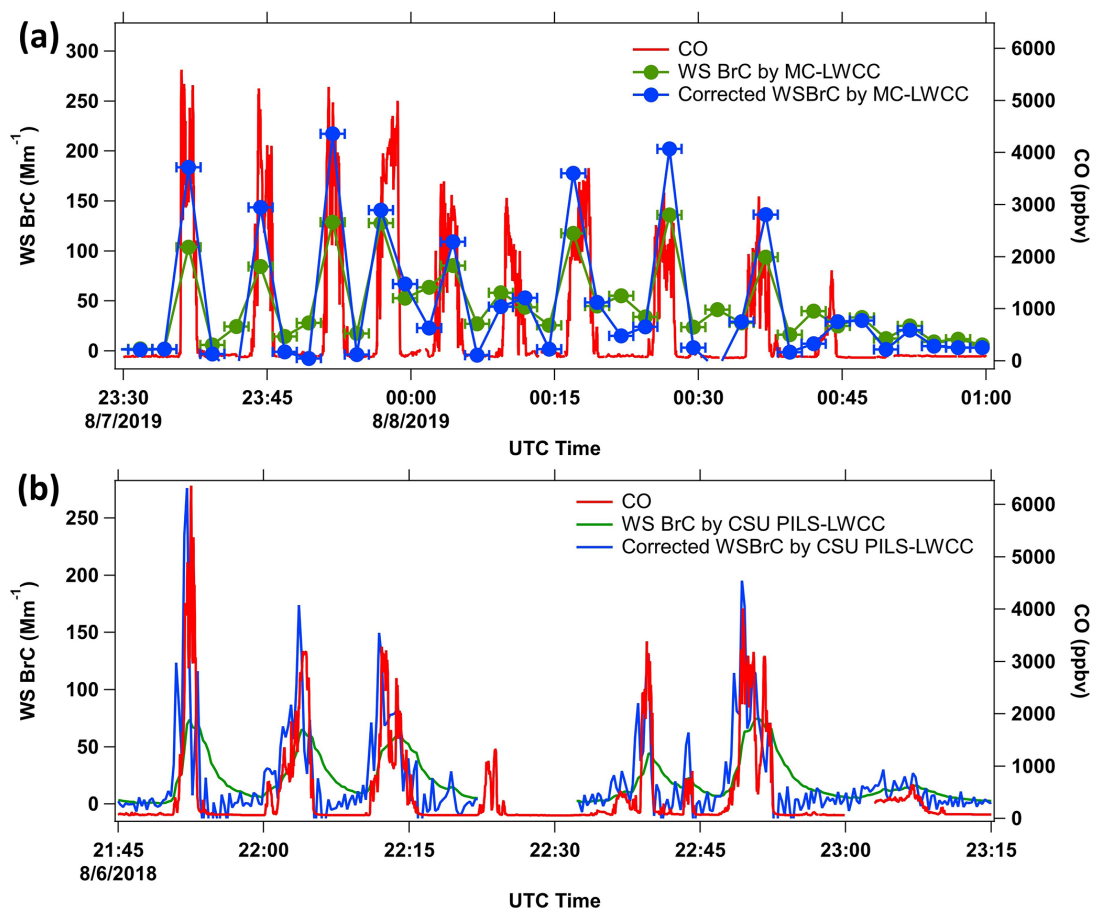

Figure 6. Time series of water-soluble $\mathrm{BrC}$ (WS $\mathrm{BrC}$ ) corrected for baseline drift and hysteresis (blue) compared to original data (green) and CO concentrations (red) for (a) the MC-LWCC measurement and (b) the CSU PILS-LWCC measurement for the same flights shown in Fig. 4a and b, respectively. Horizontal error bars in (a) represent the MC-LWCC interval.

ringe pump (i.e., first liquid in is last out, discussed above). To correct the hysteresis effect, similar assumptions noted for the MC also apply here. In this case, we assume $d \%$ of the current absorbance observation ( $\mathrm{Abs}_{j, \mathrm{observed}}$ ) is due to the current $j$ th sample $\left(\mathrm{Abs}_{j, \text { real }}\right)$, and $(1-d \%)$ absorbance is due to hysteresis $\left(\mathrm{Abs}_{j-1, \text { observed }}\right)$. The relationship can be described as

$$
\begin{aligned}
\operatorname{Abs}_{j, \text { observed }} & =d \% \times \mathrm{Abs}_{j, \text { real }}+(1-d \%) \\
& \times \mathrm{Abs}_{j-1, \text { observed }} .
\end{aligned}
$$

We also assume that WS $\mathrm{BrC}$ is nearly zero when the $\mathrm{CO}$ mixing ratio is less than $80 \mathrm{ppbv}$, which means the first term on the right side of Eq. (5) vanishes. Again, using data when the $\mathrm{C}-130$ just exited the plume and then following with 10 background samples ( $\mathrm{CO}<80 \mathrm{ppbv}$, but where WS $\mathrm{BrC}$ is not zero due to the hysteresis effect), the overdetermined system was also solved with the least squares method but this time only with one unknown, $d$. The mean and standard deviation of the factor $d$ with data from 10 plumes analyzed is $11 \pm 2$ (again, \pm is the standard deviation in $d$ determined from multiple plumes). Figure $6 \mathrm{~b}$ shows the result. The trend of the corrected WS $\mathrm{BrC}$ corresponds better with the $\mathrm{CO}$ trend but is noisier than the original data due to the corrected WS $\mathrm{BrC}$ being derived by dividing by a small number, i.e., $d \%$. The noise data may also be due to an overcorrection. The data shown in Fig. $4 \mathrm{~b}$ are the most exaggerated case of hysteresis encountered during WE-CAN. When in the smoke plumes with lower concentration, generally when $\mathrm{CO}$ was less than 2000 ppbv, the hysteresis effect was not apparent, indicating a correction may not be necessary in all cases. To remove the added noise, the data could be smoothed (over longer time intervals; $150 \mathrm{~s}$ was found to be optimal), but that will reduce the time resolution of the measurement. Similar to the $\mathrm{MC}$ results, better correlation is seen in the scatter plots between WS BrC vs. CO, shown in Fig. 7c and d, where the $R^{2}$ increases from 0.49 to 0.58 . The greater scatter for the PILS data compared to the MC is likely due to the C-130 in WE-CAN flying over more fires that were relatively small, while the DC-8 focused on larger stronger plumes in FIREXAQ. Therefore, the WE-CAN data were more influenced by variability in the WS $\mathrm{BrC}$ vs. $\mathrm{CO}$ between different smoke plumes. The hysteresis phenomenon (Fig. 3c) is not obvious for the NOAA PILS-LWCC compared with CSU PILSLWCC (Fig. 3b), possibly due to the smaller dead volume throughout the system (e.g., use of an inline bubble trap with PTFE membrane versus glass bulb debubbler), the use of a peristaltic pump versus syringe pump to move sample liquid, avoiding the syringe pump sample mixing issues, and overall lower concentrated plumes being sampled by the Twin Otter (most smoke plumes had CO below 2000 ppbv compared to typical $\mathrm{CO}$ of more than $3000 \mathrm{ppbv}$ for the plumes encountered in WE-CAN mission). Because of this, no overall hysteresis correction was performed for the NOAA PILSLWCC. 

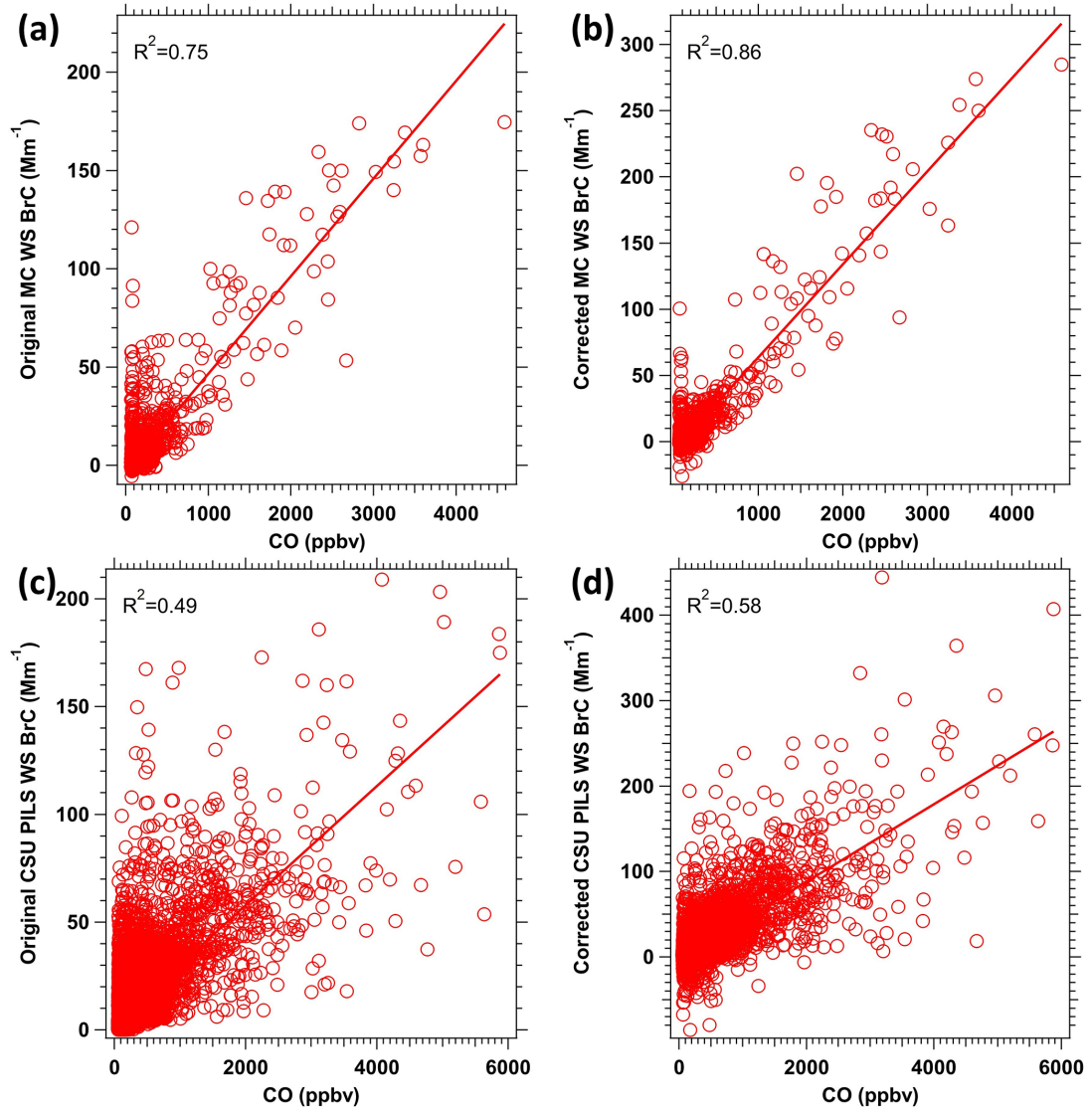

Figure 7. Scatter plots of WS BrC versus CO concentration for the MC-LWCC before (a) and after the (b) hysteresis correction and for the CSU PILS-LWCC before (c) and after the (d) hysteresis correction.

\subsection{Comparison between MC and filter measurements of $\mathrm{BrC}$}

We also compare the online WS $\mathrm{BrC}$ measurements to filter sample results, noting that the filter does not have this liquid hysteresis issue. This can only be done for the MC measurements of WS BrC since of the three aircraft, only the DC-8 included a particle filter sampling system allowing for offline $\mathrm{BrC}$ aerosol particle analysis.

The MC-LWCC BrC data with 2.5 min resolution were averaged to the lower time-resolved offline filter data. Figure 8 shows the comparison between these two methods. In the comparisons that follow, all the MC-LWCC data have been corrected for the baseline drift likely due to $\mathrm{BC}$, as discussed in Sect. 3.2. Fairly good agreement is found between the online and offline $\mathrm{BrC}$ measuring systems when not corrected for the hysteresis associated with the online data, with a slope of 0.74 and $R^{2}=0.84$. However, the agreement is better once the hysteresis correction is applied, with a slope of 0.91 and $R^{2}=0.89$. The improvement in $R^{2}$ is less than that seen for the comparison with $\mathrm{CO}$ in Fig. 7 and is likely due to averaging the $\mathrm{MC}$ WS $\mathrm{BrC}$ data to the longer filter sampling times and to most filter sampling times being re- stricted to periods within the smoke plumes (i.e., fewer data for periods of transition from within to outside of plumes). Overall, the agreement suggests that the filter measurement of $\mathrm{BrC}$ is not biased by possible sampling artifacts associated with absorption of gases or evaporative loss of $\mathrm{BrC}$ components from the filter, which is common for filter sampling of semi-volatile species but not as significant an issue for online sampling systems, such as the MC-LWCC.

\subsection{Detection limits and measurement uncertainty}

The limit of detection (LOD) and measurement uncertainty of the three instruments are presented below. The detection limits depend on the spectral integration time, sample air flow rate, volume of extraction water and also the optical path length of the waveguide.

$M C-L W C C$. The air sample flow rate directly affects the detection limit and thereby the sensitivity of the MC-LWCC for measuring $\mathrm{BrC}$. The nominal flow rate of the MC-LWCC was set to $\sim 50$ SLPM. For a given MC-LWCC design, a sufficient flow rate is necessary so that particles are efficiently scrubbed, and all internal surfaces are wetted and continually flushed. The highest flow rates possible are also limited by 

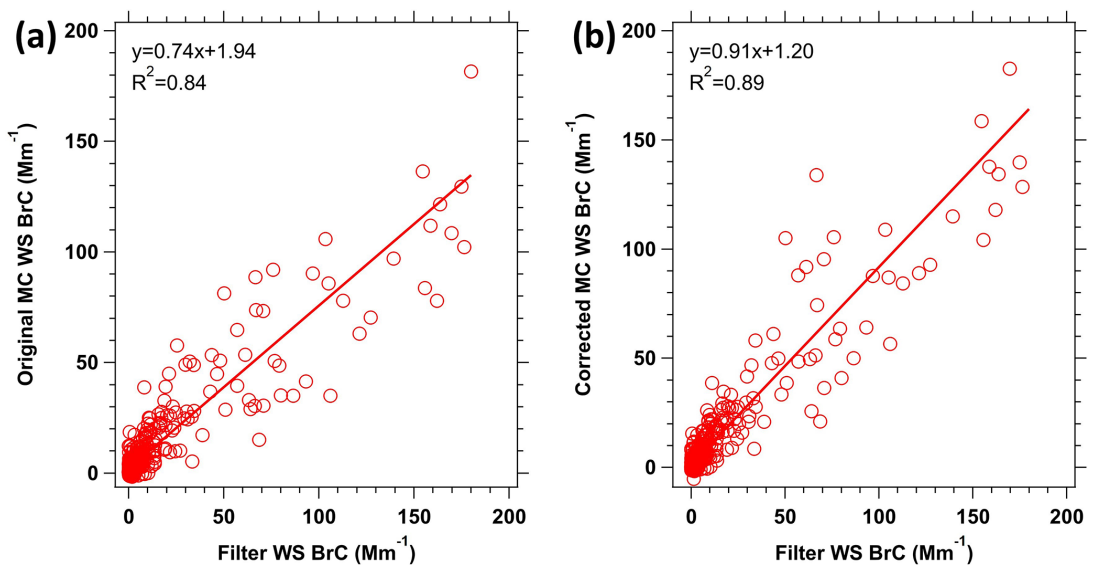

Figure 8. Comparison of the WS BrC determined online using the MC-LWCC vs. offline from extraction of filters. Panel (a) shows the original MC-LWCC WS BrC data, and panel (b) shows the MC data with the hysteresis correction applied. The data are fitted by orthogonal distance regression.

the pressure drop across the Teflon water-refluxing filter and vacuum pump size. Longer sampling times will have larger volumes of air sampled as well as cause more evaporation of the water in the MC-LWCC; both increase the sample concentration but reduce the time resolution. The water level in the MC-LWCC should be kept as low as possible to have the highest concentration but must be sufficient to maintain a reservoir in the bottom at all times while operating so that a mist is continually maintained, and all surfaces are wetted and drained during sampling. Also, there must be a sufficient sample for the various measurements. An insufficient sample can lead to drawing in air bubbles into the analytical instruments, which, depending on the amount, can invalidate the measurement or, as seen, cause extensive baseline drift.

Based on experiments, the optimal sampling time and water injection volume were found to be $150 \mathrm{~s}$ and $12 \mathrm{~mL}$ for this MC and analytical system. Approximately $10 \mathrm{~mL}$ of liquid remained in the chamber after sampling was completed. A volume of $3 \mathrm{~mL}$ of ambient sample was the maximum that could be injected into the waveguide without interference to the IC system. Occasionally, some air bubbles were introduced into the waveguide due to insufficient liquid volume left in the MC or the system leaking, as discussed above. Two cycles of liquid injection were found to be enough in most cases to remove the resulting absorption baseline drift caused by air bubbles.

The LOD is typically calculated 3 times the standard deviation of the blank measurement; however, we did not have any blank measurements involving filtering out aerosol in the MC-LWCC during the FIREX-AQ campaign. Instead, a water blank at the beginning of each flight was used, where pure water was injected into the MC and then removed and injected into the waveguide. Based on these water blanks, the LOD of the method was $0.69 \mathrm{Mm}^{-1}$, mainly due to the uncertainty associated with the spectrometer measurement. The MC-LWCC LOD was higher than the LOD for the of- fline filter method at $0.10 \mathrm{Mm}^{-1}$ due to a smaller volume of air sampled by the MC. Alternatively, MC-LWCC blank variability can be estimated when sampling in clean background air when $\mathrm{BrC}$ levels are expected to be low. For example, the flight on 19 August 2019 did not encounter any smoke plumes, and the WS BrC was very low, together with other smoke tracers $\mathrm{CO}$ and $\mathrm{BC}$. Using the time period from 19 August 2019 18:20:00-19:29:59 UTC $(\mathrm{CO}=73 \mathrm{ppb}$ and $\left.\mathrm{BC}=0.5 \mathrm{ng} \mathrm{m}^{-3}\right)$ as the blank, the LOD $(3 \sigma)$ is calculated to be $1.53 \mathrm{Mm}^{-1}$. With this LOD, only $\sim 40 \%$ of the data was above the LOD for the whole FIREX-AQ study period; data were below the LOD primarily when not sampling in smoke plumes (e.g., traveling to and from the fires and between fires). When the DC-8 was sampling smoke plumes $(\mathrm{CO}>300 \mathrm{ppbv})$, which was the main focus in FIREX-AQ, more than $90 \%$ of the MC data was above the LOD, implying that this system was mainly useful for in-plume sampling.

The uncertainty of the MC-LWCC WS BrC system was calculated by propagating the uncertainties from air sampling volume, liquid extraction volume, the spectrometer absorption measurement, baseline drift correction and hysteresis correction. Besides the hysteresis correction, the relative uncertainty for other components was approximately $5 \%$. The combined overall estimated uncertainty based on these variables was roughly $28 \%$.

PILS-LWCC. Each PILS-LWCC system acquired continuous data at $10 \mathrm{~s}$ (NOAA PILS-LWCC) or $16 \mathrm{~s}$ resolution (CSU PILS-LWCC). The measurement precision can be determined for in-flight measurements of ambient air with no detectable $\mathrm{BrC}$ absorption. Figure 9 shows an Allan deviation (Werle et al., 1993; Allan, 2016) plot for $\mathrm{Abs}_{365 \mathrm{~nm}}$ calculated for the CSU PILS-LWCC $(1 \mathrm{~h} 38 \mathrm{~m}$ period on 13 August 2018) and NOAA PILS-LWCC ( $2 \mathrm{~h} 3 \mathrm{~m}$ period on $11 \mathrm{Au}-$ gust 2019), during measurements in background air. The $1 \sigma$ Allan deviation for $30 \mathrm{~s}$ averaging is 0.29 and $0.008 \mathrm{Mm}^{-1}$ for CSU and NOAA PILS-LWCC respectively, equivalent to 


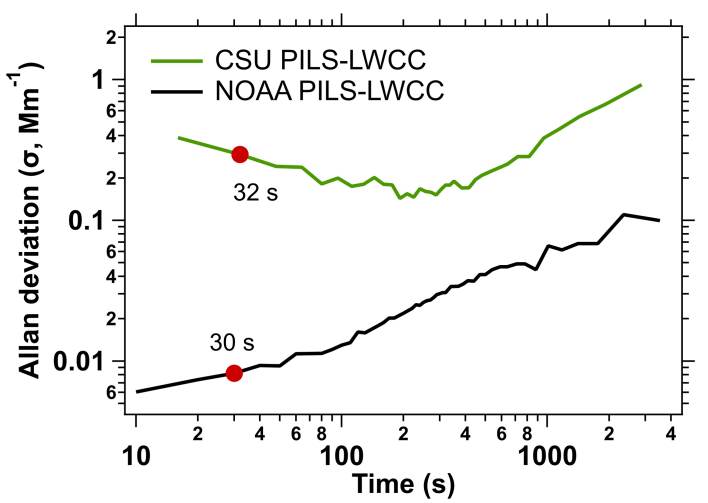

Figure 9. Allan deviation plot calculated for all WE-CAN data without plumes on Flight 10 (1:38 h from 13 August 2018 19:16:29-20:54:58 UTC) and FIREX-AQ NOAA Twin Otter flight data 11 August 2019 flight (2:03 h from 11 August 2019 22:46:0412 August 2019 00:49:54 UTC). There were no plumes during either of these periods. Data in red dots are used to determined the LOD for both systems.

$3 \sigma$ LODs of 0.89 and $0.03 \mathrm{Mm}^{-1}$, respectively. Although the NOAA PILS-LWCC shows high precision over short intervals, the Allan deviation plot indicates instrumental drift at all timescales.

The uncertainty of the CSU PILS-LWCC system was estimated to be $12 \%$ based on the uncertainties in the air and liquid flow rates and the ambient and background absorption measurement. The uncertainty of the NOAA PILS-LWCC system was calculated to be $11 \%$.

\subsection{Recommendations for further improvements}

The MC-LWCC and PILS-LWCC instruments successfully measured WS BrC throughout the WE-CAN and FIREX-AQ aircraft deployments. However, future improvements have the potential to improve the detection limits and time response of these instruments.

For the MC-LWCC, the cleaning procedure between consecutive samples was not sufficient and resulted in a large hysteresis effect (44\%) when moving in and out of smoke plumes. This could be improved by introducing a clean air flow through the MC to wash the interior wetted surfaces between samples. Shortening the tubing running between the MC and LWCC could reduce the dead volume, improving the time response and hysteresis. Arranging the MC with a minimal distance between the sample extraction port and the MC bottom would decrease the residual liquid sample within the MC (or by placing the MC sample port on the bottom of the MC body). The addition of an automated filter at the sample inlet would allow repeated blank measurements of filtered air and a better assessment of the LOD. This would also be useful in quantifying measurement hysteresis.

Increasing the sensitivity of the MC system would allow more data to be obtained, especially outside of the smoke plumes. The extraction volume and sampling flow rate cannot be significantly altered. The most effective way to increase sensitivity is to increase the sampling time, but the time resolution would decrease. Although not ideal for this study due to the fast speed of the DC-8, this could be a viable solution for ground-based studies, where decreasing the time resolution from $2.5 \mathrm{~min}$ to 30 or $60 \mathrm{~min}$ may still produce acceptable time-resolved data, with 12 to 24 times improvement in the sensitivity (lower LOD). This higher sensitivity could also reduce measurement uncertainty.

For the PILS-LWCC, time response could be improved and hysteresis reduced by using a peristaltic pump instead of syringe pumps to move the liquid sample from the PILS to the LWCC and by decreasing the volume between the impaction plate to the LWCC and any places where liquid gets stalled in the system. This would entail using short smallbore tubing and the smallest internal volume possible for the debubbler (e.g., use of a inline bubble trap with PTFE membrane with vacuum assist) and liquid filter and reducing the dead volume in the syringe pumps (i.e., using a cone tip instead of a flat tip on the piston).

For all liquid systems, adding surfactants to the water to reduce the water surface tension can reduce hysteresis (Rastogi et al., 2009) but must be selected so as not to interfere with the analytical systems. It is known that introduction of air bubbles in the sample line, that are completely removed just upstream of the LWCC, can reduce hysteresis by "wiping" the walls of the wetted surfaces as they pass through the liquid system.

Drift in the light source intensity may contribute to instrument drift, seen in the Allan deviation plot in Fig. 9. This could be improved by temperature-controlling the light source and monitoring its output intensity. The pressurecontrolled inlet system for the NOAA-PILS also seems to have distinct advantages since it allowed the use of the peristaltic pumping system instead of syringe pumps and likely dampens other variability in the complete PILS-LWCC due to changes in ambient pressure with aircraft altitude changes and possible turbulence in the inlet and air sample lines.

\section{Conclusion}

We present a comparison of three WS $\mathrm{BrC}$ measuring systems, including two PILS-LWCC systems and a newly developed MC-LWCC. The new system was based on expanding the analytical capabilities of a mist chamber (MC) sampling system on the NASA DC-8 research aircraft which had been extensively used in past studies for measuring inorganic gases and aerosol particles. The new system was deployed during the NASA FIREX-AQ and contrasted with the performance of the PILS-LWCC systems for measuring WS BrC on the NSF C-130 aircraft as part of WE-CAN and on the NOAA Twin Otter during FIREX-AQ. These three systems used almost identical $\mathrm{BrC}$ analytical methods (LWCCs and 
spectrophotometers) to determine levels of light-absorbing chromophores in liquid water samples, whereas the particle collection and liquid handling systems differed. Using a dual MC system operating in batch mode, the MC-LWCC measurement time resolution was $2.5 \mathrm{~min}$. Sampling air at 50 SLPM with $12 \mathrm{~mL}$ of collection water and a $2.5 \mathrm{~m}$ long LWCC, the LOD of the system for measuring WS BrC was $1.53 \mathrm{Mm}^{-1}$, with an estimated $28 \%$ uncertainty. For comparison, the filter sampling system with offline analysis of $\mathrm{BrC}$ using an identical LWCC and a spectrophotometer had a LOD of $0.10 \mathrm{Mm}^{-1}$ and uncertainty of $16 \%$. The CSU PILSLWCC system sampling at an air flow rate of 15 SLPM had a LOD of $0.89 \mathrm{Mm}^{-1}$ and uncertainty of $12 \%$, and NOAA PILS-LWCC with 6SLPM had a LOD of $0.03 \mathrm{Mm}^{-1}$ and uncertainty of $11 \%$, both operating as continuous samplers. Spectral drift due to air bubbles in the sample line and BC that passed the liquid particle filter was an issue with the MC-LWCC, but this was not as apparent in the PILS-LWCC systems and had no effect on the filter sampling method. Hysteresis (smearing) of samples between consecutive measurements was a major artifact in this study for the MC-LWCC and on many occasions for the CSU PILS-LWCC, which was clearly seen in this study of smoke plumes measured near the fires. For the MC-LWCC, the hysteresis was largely due to not completely flushing the MC with clean water and not generating a mist to wash all internal surfaces, with a minor contribution from hysteresis in the sample lines. For the CSU PILS-LWCC, hysteresis issues were due to the size of the wetted area of the impaction plate (which was small, a specific design feature of the system) and the liquid flow system that included the debubbler, liquid filter, syringe pumps and sample lines. A hysteresis correction results in sharper changes in concentrations that more closely track changes in $\mathrm{CO}$ when transitioning from sampling in and out of wildfire smoke plumes with the aircraft (average aircraft speed for NASA DC- $8=200 \mathrm{~m} \mathrm{~s}^{-1}$ and for NSF C-130 $=100 \mathrm{~m} \mathrm{~s}^{-1}$ ) and increases the in-plume $\mathrm{BrC}$ levels but produced more variability (noise) in the CSU PILS-LWCC dataset. The NOAA PILS-LWCC showed very little evidence of sample hysteresis, possibly due to the different liquid sample flow system that used peristaltic versus syringe pumps (e.g., for each stroke first liquid into pump is last out) to move the sample liquid and the overall lower concentrated plumes encountered. For the MC-LWCC, the online WS BrC data were in good agreement with the offline WS $\mathrm{BrC}$ measured with filters, with a regression slope of 0.91 and $R^{2}=0.89$. Since the MC-LWCC should not be susceptible to WS BrC volatility artifacts known to occur in filter sampling, the good agreement suggests that there are few artifacts associated with the filter method and that much of the $\mathrm{BrC}$ was likely not highly volatile. In this study, the MC-LWCC was only of sufficient sensitivity to measure $\mathrm{BrC}$ levels in smoke plumes; the filter sampling system with much higher mass loading $(\sim 20$ times higher) could measure WS BrC, even in continental background conditions. As this was the first attempt at WS BrC measurements with a mist chamber, possible improvements to the MC-LWCC system were proposed.

Data availability. FIREX-AQ data can be downloaded from the NOAA/NASA FIREX-AQ data archive at https://doi.org/10.5067/SUBORBITAL/FIREXAQ2019/DATA001 (NASA, 2021). WE-CAN data can be found at https: //data.eol.ucar.edu/project/WE-CAN (NCAR, 2018).

Author contributions. RJW and JD provided the original idea of building the MC-LWCC. LZ and ES designed and built the MCLWCC. APS was responsible for CSU PILS-LWCC, and RAW was responsible for NOAA PILS-LWCC. TLC, JMK, EJTL and MAR made other measurements on the aircraft. LZ, APS and RAW analyzed BrC data. LZ and RJW prepared the manuscript with contributions from all co-authors.

Competing interests. The contact author has declared that neither they nor their co-authors have any competing interests.

Disclaimer. Publisher's note: Copernicus Publications remains neutral with regard to jurisdictional claims in published maps and institutional affiliations.

Acknowledgements. This work was supported by NASA (grant no. 80NSSC18K0662), NSF (grant no. AGS-1650786) and NOAA (grant no. NA17OAR4310010). The authors thank Delphine Farmer, Sonia Kreidenweis and Paul DeMott for the WECAN SP-2 data, Glenn Diskin for CO data and Joshua Schwarz for BC FIREX data. We also thank all pilots and crew of the NASA DC-8, NSF C-130 and NOAA Twin Otter.

Financial support. This research has been supported by the NASA (grant no. 80NSSC18K0662), NSF (grant no. AGS-1650786), and the NOAA (grant no. NA17OAR4310010).

Review statement. This paper was edited by Hang Su and reviewed by two anonymous referees.

\section{References}

Adachi, K., Sedlacek, A. J., Kleinman, L., Springston, S. R., Wang, J., Chand, D., Hubbe, J. M., Shilling, J. E., Onasch, T. B., Kinase, T., Sakata, K., Takahashi, Y., and Buseck, P. R.: Spherical tarball particles form through rapid chemical and physical changes of organic matter in biomass-burning smoke, P. Natl. Acad. Sci. USA, 116, 19336, https://doi.org/10.1073/pnas.1900129116, 2019.

Adler, G., Wagner, N. L., Lamb, K. D., Manfred, K. M., Schwarz, J. P., Franchin, A., Middlebrook, A. M., Washen- 
felder, R. A., Womack, C. C., Yokelson, R. J., and Murphy, D. M.: Evidence in biomass burning smoke for a light-absorbing aerosol with properties intermediate between brown and black carbon, Aerosol Sci. Tech., 53, 976-989, https://doi.org/10.1080/02786826.2019.1617832, 2019.

Allan, D. W.: Historicity, strengths, and weaknesses of Allan variances and their general applications, Gyroscopy and Navigation, 7, 1-17, https://doi.org/10.1134/S2075108716010028, 2016.

Andreae, M. O. and Gelencsér, A.: Black carbon or brown carbon? The nature of light-absorbing carbonaceous aerosols, Atmos. Chem. Phys., 6, 3131-3148, https://doi.org/10.5194/acp-63131-2006, 2006.

Arnott, W. P., Moosmüller, H., Rogers, C. F., Jin, T., and Bruch, R.: Photoacoustic spectrometer for measuring light absorption by aerosol: instrument description, Atmos. Environ., 33, 28452852, https://doi.org/10.1016/S1352-2310(98)00361-6, 1999.

Bandowe, B. A. M. and Meusel, H.: Nitrated polycyclic aromatic hydrocarbons (nitro-PAHs) in the environment - A review, Sci. Total Environ., 581-582, 237-257, https://doi.org/10.1016/j.scitotenv.2016.12.115, 2017.

Bergstrom, R. W., Pilewskie, P., Russell, P. B., Redemann, J., Bond, T. C., Quinn, P. K., and Sierau, B.: Spectral absorption properties of atmospheric aerosols, Atmos. Chem. Phys., 7, 5937-5943, https://doi.org/10.5194/acp-7-5937-2007, 2007.

Bond, T. C. and Bergstrom, R. W.: Light Absorption by Carbonaceous Particles: An Investigative Review, Aerosol Sci. Tech., 40, 27-67, https://doi.org/10.1080/02786820500421521, 2006.

Bond, T. C., Anderson, T. L., and Campbell, D.: Calibration and Intercomparison of Filter-Based Measurements of Visible Light Absorption by Aerosols, Aerosol Sci. Tech., 30, 582-600, https://doi.org/10.1080/027868299304435, 1999.

Bond, T. C., Doherty, S. J., Fahey, D. W., Forster, P. M., Berntsen, T., DeAngelo, B. J., Flanner, M. G., Ghan, S., Kärcher, B., Koch, D., Kinne, S., Kondo, Y., Quinn, P. K., Sarofim, M. C., Schultz, M. G., Schulz, M., Venkataraman, C., Zhang, H., Zhang, S., Bellouin, N., Guttikunda, S. K., Hopke, P. K., Jacobson, M. Z., Kaiser, J. W., Klimont, Z., Lohmann, U., Schwarz, J. P., Shindell, D., Storelvmo, T., Warren, S. G., and Zender, C. S.: Bounding the role of black carbon in the climate system: A scientific assessment, J. Geophys. Res.-Atmos., 118, 5380-5552, https://doi.org/10.1002/jgrd.50171, 2013.

Cappa, C. D., Onasch, T. B., Massoli, P., Worsnop, D. R., Bates, T. S., Cross, E. S., Davidovits, P., Hakala, J., Hayden, K. L., Jobson, B. T., Kolesar, K. R., Lack, D. A., Lerner, B. M., Li, S.-M., Mellon, D., Nuaaman, I., Olfert, J. S., Petäjä, T., Quinn, P. K., Song, C., Subramanian, R., Williams, E. J., and Zaveri, R. A.: Radiative Absorption Enhancements Due to the Mixing State of Atmospheric Black Carbon, Science, 337, 1078, https://doi.org/10.1126/science.1223447, 2012.

Cappa, C. D., Zhang, X., Russell, L. M., Collier, S., Lee, A. K. Y., Chen, C.-L., Betha, R., Chen, S., Liu, J., Price, D. J., Sanchez, K. J., McMeeking, G. R., Williams, L. R., Onasch, T. B., Worsnop, D. R., Abbatt, J., and Zhang, Q.: Light Absorption by Ambient Black and Brown Carbon and its Dependence on Black Carbon Coating State for Two California, USA, Cities in Winter and Summer, J. Geophys. Res.-Atmos., 124, 1550-1577, https://doi.org/10.1029/2018jd029501, 2019.

Chakrabarty, R. K., Moosmüller, H., Chen, L.-W. A., Lewis, K., Arnott, W. P., Mazzoleni, C., Dubey, M. K., Wold, C. E., Hao,
W. M., and Kreidenweis, S. M.: Brown carbon in tar balls from smoldering biomass combustion, Atmos. Chem. Phys., 10, 63636370, https://doi.org/10.5194/acp-10-6363-2010, 2010.

Chen, Y. and Bond, T. C.: Light absorption by organic carbon from wood combustion, Atmos. Chem. Phys., 10, 1773-1787, https://doi.org/10.5194/acp-10-1773-2010, 2010.

Cheng, Z., Atwi, K., Hajj, O. E., Ijeli, I., Fischer, D. A., Smith, G., and Saleh, R.: Discrepancies between brown carbon light-absorption properties retrieved from online and offline measurements, Aerosol Sci. Tech., 55, 92-103, https://doi.org/10.1080/02786826.2020.1820940, 2021.

Cofer, W. R. and Edahl, R. A.: A new technique for collection, concentration and determination of gaseous tropospheric formaldehyde, Atmos. Environ., 20, 979-984, https://doi.org/10.1016/0004-6981(86)90282-9, 1986.

Cofer, W. R., Collins, V. G., and Talbot, R. W.: Improved aqueous scrubber for collection of soluble atmospheric trace gases, Environ. Sci. Technol., 19, 557-560, https://doi.org/10.1021/es00136a012, 1985.

Craig, L., Moharreri, A., Schanot, A., Rogers, D. C., Anderson, B., and Dhaniyala, S.: Characterizations of Cloud Droplet Shatter Artifacts in Two Airborne Aerosol Inlets, Aerosol Sci. Tech., 47, 662-671, https://doi.org/10.1080/02786826.2013.780648, 2013a.

Craig, L., Schanot, A., Moharreri, A., Rogers, D. C., and Dhaniyala, S.: Design and Sampling Characteristics of a New Airborne Aerosol Inlet for Aerosol Measurements in Clouds, J. Atmos. Ocean. Tech., 30, 1123-1135, https://doi.org/10.1175/jtech-d12-00168.1, 2013b.

Craig, L., Moharreri, A., Rogers, D. C., Anderson, B., and Dhaniyala, S.: Aircraft-Based Aerosol Sampling in Clouds: Performance Characterization of Flow-Restriction Aerosol Inlets, J. Atmos. Ocean. Tech., 31, 2512-2521, https://doi.org/10.1175/jtech-d-14-00022.1, 2014.

Crosson, E. R.: A cavity ring-down analyzer for measuring atmospheric levels of methane, carbon dioxide, and water vapor, Applied Physics B-Lasers O., 92, 403-408, https://doi.org/10.1007/s00340-008-3135-y, 2008.

Desyaterik, Y., Sun, Y., Shen, X., Lee, T., Wang, X., Wang, T., and Collett Jr., J. L.: Speciation of "brown" carbon in cloud water impacted by agricultural biomass burning in eastern China, J. Geophys. Res.-Atmos., 118, 7389-7399, https://doi.org/10.1002/jgrd.50561, 2013.

Dibb, J. E., Talbot, R. W., Scheuer, E., Seid, G., DeBell, L., Lefer, B., and Ridley, B.: Stratospheric influence on the northern North American free troposphere during TOPSE: 7Be as a stratospheric tracer, J. Geophys. Res.-Atmos., 108, 8863, https://doi.org/10.1029/2001JD001347, 2003.

Eatough, D. J., Wadsworth, A., Eatough, D. A., Crawford, J. W., Hansen, L. D., and Lewis, E. A.: A multiple-system, multi-channel diffusion denuder sampler for the determination of fine-particulate organic material in the atmosphere, Atmos. Environ. A-Gen., 27, 1213-1219, https://doi.org/10.1016/09601686(93)90247-V, 1993.

Feng, Y., Ramanathan, V., and Kotamarthi, V. R.: Brown carbon: a significant atmospheric absorber of solar radiation?, Atmos. Chem. Phys., 13, 8607-8621, https://doi.org/10.5194/acp13-8607-2013, 2013. 
Gao, D., Godri Pollitt, K. J., Mulholland, J. A., Russell, A. G., and Weber, R. J.: Characterization and comparison of $\mathrm{PM}_{2} .5$ oxidative potential assessed by two acellular assays, Atmos. Chem. Phys., 20, 5197-5210, https://doi.org/10.5194/acp-205197-2020, 2020a.

Gao, D., Mulholland, J. A., Russell, A. G., and Weber, R. J.: Characterization of water-insoluble oxidative potential of $\mathrm{PM}_{2.5}$ using the dithiothreitol assay, Atmos. Environ., 224, 117327, https://doi.org/10.1016/j.atmosenv.2020.117327, 2020b.

Gomes, M. S. P., Pui, D. Y. H., Vincent, J. H., and Liu, B. Y. H.: Convective and diffusive dispersion of particles in laminar tube flow: Effects on time-dependent concentration measurements, J. Aerosol Sci., 24, 643-654, https://doi.org/10.1016/00218502(93)90021-Z, 1993.

Hecobian, A., Zhang, X., Zheng, M., Frank, N., Edgerton, E. S., and Weber, R. J.: Water-Soluble Organic Aerosol material and the light-absorption characteristics of aqueous extracts measured over the Southeastern United States, Atmos. Chem. Phys., 10, 5965-5977, https://doi.org/10.5194/acp-10-5965-2010, 2010.

Hinrichs, R. Z., Buczek, P., and Trivedi, J. J.: Solar Absorption by Aerosol-Bound Nitrophenols Compared to Aqueous and Gaseous Nitrophenols, Environ. Sci. Technol., 50, 5661-5667, https://doi.org/10.1021/acs.est.6b00302, 2016.

Holben, B. N., Eck, T. F., Slutsker, I., Tanré, D., Buis, J. P., Setzer, A., Vermote, E., Reagan, J. A., Kaufman, Y. J., Nakajima, T., Lavenu, F., Jankowiak, I., and Smirnov, A.: AERONET - A Federated Instrument Network and Data Archive for Aerosol Characterization, Remote Sens. Environ., 66, 1-16, https://doi.org/10.1016/S0034-4257(98)00031-5, 1998.

Jacobson, M. Z.: Strong radiative heating due to the mixing state of black carbon in atmospheric aerosols, Nature, 409, 695-697, https://doi.org/10.1038/35055518, 2001.

Jo, D. S., Park, R. J., Lee, S., Kim, S.-W., and Zhang, X.: A global simulation of brown carbon: implications for photochemistry and direct radiative effect, Atmos. Chem. Phys., 16, 3413-3432, https://doi.org/10.5194/acp-16-3413-2016, 2016.

Karion, A., Sweeney, C., Wolter, S., Newberger, T., Chen, H., Andrews, A., Kofler, J., Neff, D., and Tans, P.: Long-term greenhouse gas measurements from aircraft, Atmos. Meas. Tech., 6, 511-526, https://doi.org/10.5194/amt-6-511-2013, 2013.

Koch, D., Bond, T. C., Streets, D., Unger, N., and van der Werf, G. R.: Global impacts of aerosols from particular source regions and sectors, J. Geophys. Res.-Atmos., 112, D02205, https://doi.org/10.1029/2005jd007024, 2007.

Lack, D. A. and Cappa, C. D.: Impact of brown and clear carbon on light absorption enhancement, single scatter albedo and absorption wavelength dependence of black carbon, Atmos. Chem. Phys., 10, 4207-4220, https://doi.org/10.5194/acp10-4207-2010, 2010.

Lack, D. A. and Langridge, J. M.: On the attribution of black and brown carbon light absorption using the Ångström exponent, Atmos. Chem. Phys., 13, 10535-10543, https://doi.org/10.5194/acp-13-10535-2013, 2013.

Lack, D. A., Cappa, C. D., Covert, D. S., Baynard, T., Massoli, P., Sierau, B., Bates, T. S., Quinn, P. K., Lovejoy, E. R., and Ravishankara, A. R.: Bias in Filter-Based Aerosol Light Absorption Measurements Due to Organic Aerosol Loading: Evidence from Ambient Measurements, Aerosol Sci. Tech., 42, 1033-1041, https://doi.org/10.1080/02786820802389277, 2008.
Lack, D. A., Langridge, J. M., Bahreini, R., Cappa, C. D., Middlebrook, A. M., and Schwarz, J. P.: Brown carbon and internal mixing in biomass burning particles, P. Natl. Acad. Sci. USA, 109, 14802-14807, https://doi.org/10.1073/pnas.1206575109, 2012.

Lan, Z.-J., Huang, X.-F., Yu, K.-Y., Sun, T.-L., Zeng, L.W., and Hu, M.: Light absorption of black carbon aerosol and its enhancement by mixing state in an urban atmosphere in South China, Atmos. Environ., 69, 118-123, https://doi.org/10.1016/j.atmosenv.2012.12.009, 2013.

Langridge, J. M., Richardson, M. S., Lack, D. A., Brock, C. A., and Murphy, D. M.: Limitations of the Photoacoustic Technique for Aerosol Absorption Measurement at High Relative Humidity, Aerosol Sci. Tech., 47, 1163-1173, https://doi.org/10.1080/02786826.2013.827324, 2013.

Li, J., Liu, C., Yin, Y., and Kumar, K. R.: Numerical investigation on the Angström exponent of black carbon aerosol, J. Geophys. Res.-Atmos., 121, 3506-3518, https://doi.org/10.1002/2015JD024718, 2016.

Lin, C.-I., Baker, M., and Charlson, R. J.: Absorption Coefficient of Atmospheric Aerosol: a Method for Measurement, Appl. Opt., 12, 1356-1363, https://doi.org/10.1364/AO.12.001356, 1973.

Liu, J., Bergin, M., Guo, H., King, L., Kotra, N., Edgerton, E., and Weber, R. J.: Size-resolved measurements of brown carbon in water and methanol extracts and estimates of their contribution to ambient fine-particle light absorption, Atmos. Chem. Phys., 13, 12389-12404, https://doi.org/10.5194/acp-13-123892013, 2013.

Liu, J., Scheuer, E., Dibb, J., Ziemba, L. D., Thornhill, K. L., Anderson, B. E., Wisthaler, A., Mikoviny, T., Devi, J. J., Bergin, M., and Weber, R. J.: Brown carbon in the continental troposphere, Geophys. Res. Lett., 41, 2191-2195, https://doi.org/10.1002/2013GL058976, 2014.

Liu, J., Scheuer, E., Dibb, J., Diskin, G. S., Ziemba, L. D., Thornhill, K. L., Anderson, B. E., Wisthaler, A., Mikoviny, T., Devi, J. J., Bergin, M., Perring, A. E., Markovic, M. Z., Schwarz, J. P., Campuzano-Jost, P., Day, D. A., Jimenez, J. L., and Weber, R. J.: Brown carbon aerosol in the North American continental troposphere: sources, abundance, and radiative forcing, Atmos. Chem. Phys., 15, 7841-7858, https://doi.org/10.5194/acp15-7841-2015, 2015.

Liu, S., Aiken, A. C., Gorkowski, K., Dubey, M. K., Cappa, C. D., Williams, L. R., Herndon, S. C., Massoli, P., Fortner, E. C., Chhabra, P. S., Brooks, W. A., Onasch, T. B., Jayne, J. T., Worsnop, D. R., China, S., Sharma, N., Mazzoleni, C., Xu, L., Ng, N. L., Liu, D., Allan, J. D., Lee, J. D., Fleming, Z. L., Mohr, C., Zotter, P., Szidat, S., and Prévôt, A. S. H.: Enhanced light absorption by mixed source black and brown carbon particles in UK winter, Nat. Commun., 6, 8435, https://doi.org/10.1038/ncomms9435, 2015.

Marple, V. A., Rubow, K. L., and Behm, S. M.: A Microorifice Uniform Deposit Impactor (MOUDI): Description, Calibration, and Use, Aerosol Sci. Tech., 14, 434-446, https://doi.org/10.1080/02786829108959504, 1991.

McNaughton, C. S., Clarke, A. D., Howell, S. G., Pinkerton, M., Anderson, B., Thornhill, L., Hudgins, C., Winstead, E., Dibb, J. E., Scheuer, E., and Maring, H.: Results from the DC-8 Inlet Characterization Experiment (DICE): Airborne Versus Surface Sampling of Mineral Dust 
and Sea Salt Aerosols, Aerosol Sci. Tech., 41, 136-159, https://doi.org/10.1080/02786820601118406, 2007.

Moharreri, A., Craig, L., Dubey, P., Rogers, D. C., and Dhaniyala, S.: Aircraft testing of the new Blunt-body Aerosol Sampler (BASE), Atmos. Meas. Tech., 7, 3085-3093, https://doi.org/10.5194/amt-7-3085-2014, 2014.

Mohr, C., Lopez-Hilfiker, F. D., Zotter, P., Prévôt, A. S. H., Xu, L., Ng, N. L., Herndon, S. C., Williams, L. R., Franklin, J. P., Zahniser, M. S., Worsnop, D. R., Knighton, W. B., Aiken, A. C., Gorkowski, K. J., Dubey, M. K., Allan, J. D., and Thornton, J. A.: Contribution of Nitrated Phenols to Wood Burning Brown Carbon Light Absorption in Detling, United Kingdom during Winter Time, Environ. Sci. Technol., 47, 6316-6324, https://doi.org/10.1021/es400683v, 2013.

Myhre, G., Hoyle, C. R., Berglen, T. F., Johnson, B. T., and Haywood, J. M.: Modeling of the solar radiative impact of biomass burning aerosols during the Dust and Biomass-burning Experiment (DABEX), J. Geophys. Res.-Atmos., 113, D00C16, https://doi.org/10.1029/2008jd009857, 2008.

NASA: Fire Influence on Regional to Global Environments and Air Quality, NASA Earthdata [data set], https://doi.org/10.5067/SUBORBITAL/FIREXAQ2019/DATA001, 2021.

NCAR: WE-CAN: Western Wildfire Experiment for Cloud Chemistry, Aerosol, Absorption and Nitrogen, Earth Observing Laboratory [data set], available at: https://data.eol.ucar.edu/project/ WE-CAN (last access: 18 September 2021), 2018.

Olson, M. R., Victoria Garcia, M., Robinson, M. A., Van Rooy, P., Dietenberger, M. A., Bergin, M., and Schauer, J. J.: Investigation of black and brown carbon multiple-wavelengthdependent light absorption from biomass and fossil fuel combustion source emissions, J. Geophys. Res.-Atmos., 120, 66826697, https://doi.org/10.1002/2014JD022970, 2015.

Orsini, D. A., Ma, Y., Sullivan, A., Sierau, B., Baumann, K., and Weber, R. J.: Refinements to the particle-into-liquid sampler (PILS) for ground and airborne measurements of water soluble aerosol composition, Atmos. Environ., 37, 1243-1259, https://doi.org/10.1016/S1352-2310(02)01015-4, 2003.

Peltier, R. E., Weber, R. J., and Sullivan, A. P.: Investigating a Liquid-Based Method for Online Organic Carbon Detection in Atmospheric Particles, Aerosol Sci. Tech., 41, 1117-1127, https://doi.org/10.1080/02786820701777465, 2007.

Perring, A. E., Schwarz, J. P., Gao, R. S., Heymsfield, A. J., Schmitt, C. G., Schnaiter, M., and Fahey, D. W.: Evaluation of a Perpendicular Inlet for Airborne Sampling of Interstitial Submicron Black-Carbon Aerosol, Aerosol Sci. Tech., 47, 1066-1072, https://doi.org/10.1080/02786826.2013.821196, 2013.

Phillips, S. M. and Smith, G. D.: Spectroscopic comparison of water- and methanol-soluble brown carbon particulate matter, Aerosol Sci. Tech., 51, 1113-1121, https://doi.org/10.1080/02786826.2017.1334109, 2017.

Phillips, S. M., Bellcross, A. D., and Smith, G. D.: Light Absorption by Brown Carbon in the Southeastern United States is pH-dependent, Environ. Sci. Technol., 51, 6782-6790, https://doi.org/10.1021/acs.est.7b01116, 2017.

Pósfai, M., Gelencsér, A., Simonics, R., Arató, K., Li, J., Hobbs, P. V., and Buseck, P. R.: Atmospheric tar balls: Particles from biomass and biofuel burning, J. Geophys. Res.-Atmos., 109, D06213, https://doi.org/10.1029/2003jd004169, 2004.
Rastogi, N., Oakes, M. M., Schauer, J. J., Shafer, M. M., Majestic, B. J., and Weber, R. J.: New Technique for Online Measurement of Water-Soluble Fe(II) in Atmospheric Aerosols, Environ. Sci. Technol., 43, 2425-2430, https://doi.org/10.1021/es8031902, 2009.

Saleh, R., Marks, M., Heo, J., Adams, P. J., Donahue, N. M., and Robinson, A. L.: Contribution of brown carbon and lensing to the direct radiative effect of carbonaceous aerosols from biomass and biofuel burning emissions, J. Geophys. Res.-Atmos., 120, 10285-210296, https://doi.org/10.1002/2015JD023697, 2015.

Saleh, R., Cheng, Z., and Atwi, K.: The Brown-Black Continuum of Light-Absorbing Combustion Aerosols, Environ. Sci. Tech. Let., 5, 508-513, https://doi.org/10.1021/acs.estlett.8b00305, 2018.

Scheuer, E., Talbot, R. W., Dibb, J. E., Seid, G. K., DeBell, L., and Lefer, B.: Seasonal distributions of fine aerosol sulfate in the North American Arctic basin during TOPSE, J. Geophys. Res.-Atmos., 108, 8370, https://doi.org/10.1029/2001JD001364, 2003.

Schnaiter, M., Linke, C., Möhler, O., Naumann, K.-H., Saathoff, H., Wagner, R., Schurath, U., and Wehner, B.: Absorption amplification of black carbon internally mixed with secondary organic aerosol, J. Geophys. Res.-Atmos., 110, D19204, https://doi.org/10.1029/2005JD006046, 2005.

Schwarz, J. P., Gao, R. S., Fahey, D. W., Thomson, D. S., Watts, L. A., Wilson, J. C., Reeves, J. M., Darbeheshti, M., Baumgardner, D. G., Kok, G. L., Chung, S. H., Schulz, M., Hendricks, J., Lauer, A., Kärcher, B., Slowik, J. G., Rosenlof, K. H., Thompson, T. L., Langford, A. O., Loewenstein, M., and Aikin, K. C.: Single-particle measurements of midlatitude black carbon and light-scattering aerosols from the boundary layer to the lower stratosphere, J. Geophys. Res.-Atmos., 111, D16207, https://doi.org/10.1029/2006JD007076, 2006.

Schwarz, J. P., Spackman, J. R., Fahey, D. W., Gao, R. S., Lohmann, U., Stier, P., Watts, L. A., Thomson, D. S., Lack, D. A., Pfister, L., Mahoney, M. J., Baumgardner, D., Wilson, J. C., and Reeves, J. M.: Coatings and their enhancement of black carbon light absorption in the tropical atmosphere, J. Geophys. Res.-Atmos., 113, D03203, https://doi.org/10.1029/2007JD009042, 2008.

Sedlacek III, A. J., Lewis, E. R., Kleinman, L., Xu, J., and Zhang, Q.: Determination of and evidence for non-core-shell structure of particles containing black carbon using the Single-Particle Soot Photometer (SP2), Geophys. Res. Lett., 39, L06802, https://doi.org/10.1029/2012GL050905, 2012.

Spaulding, R. S., Talbot, R. W., and Charles, M. J.: Optimization of a Mist Chamber (Cofer Scrubber) for Sampling WaterSoluble Organics in Air, Environ. Sci. Technol., 36, 1798-1808, https://doi.org/10.1021/es011189x, 2002.

Subramanian, R., Roden, C. A., Boparai, P., and Bond, T. C.: Yellow Beads and Missing Particles: Trouble Ahead for FilterBased Absorption Measurements, Aerosol Sci. Tech., 41, 630 637, https://doi.org/10.1080/02786820701344589, 2007.

Sullivan, A. P., Peltier, R. E., Brock, C. A., de Gouw, J. A., Holloway, J. S., Warneke, C., Wollny, A. G., and Weber, R. J.: Airborne measurements of carbonaceous aerosol soluble in water over northeastern United States: Method development and an investigation into water-soluble organic carbon sources, J. Geophys. Res.-Atmos., 111, D23S46, https://doi.org/10.1029/2006JD007072, 2006. 
Sullivan, A. P., May, A. A., Lee, T., McMeeking, G. R., Kreidenweis, S. M., Akagi, S. K., Yokelson, R. J., Urbanski, S. P., and Collett Jr., J. L.: Airborne characterization of smoke marker ratios from prescribed burning, Atmos. Chem. Phys., 14, 1053510545, https://doi.org/10.5194/acp-14-10535-2014, 2014.

Sullivan, A. P., Guo, H., Schroder, J. C., Campuzano-Jost, P., Jimenez, J. L., Campos, T., Shah, V., Jaeglé, L., Lee, B. H., Lopez-Hilfiker, F. D., Thornton, J. A., Brown, S. S., and Weber, R. J.: Biomass Burning Markers and Residential Burning in the WINTER Aircraft Campaign, J. Geophys. Res.-Atmos., 124, 1846-1861, https://doi.org/10.1029/2017JD028153, 2019.

Talbot, R. W., Dibb, J. E., Scheuer, E. M., Kondo, Y., Koike, M., Singh, H. B., Salas, L. B., Fukui, Y., Ballenthin, J. O., Meads, R. F., Miller, T. M., Hunton, D. E., Viggiano, A. A., Blake, D. R., Blake, N. J., Atlas, E., Flocke, F., Jacob, D. J., and Jaegle, L.: Reactive nitrogen budget during the NASA SONEX Mission, Geophys. Res. Lett., 26, 3057-3060, https://doi.org/10.1029/1999GL900589, 1999.

Teich, M., van Pinxteren, D., Wang, M., Kecorius, S., Wang, Z., Müller, T., Močnik, G., and Herrmann, H.: Contributions of nitrated aromatic compounds to the light absorption of watersoluble and particulate brown carbon in different atmospheric environments in Germany and China, Atmos. Chem. Phys., 17, 1653-1672, https://doi.org/10.5194/acp-17-1653-2017, 2017.

Tian, Z., Zhao, H., Peter, K. T., Gonzalez, M., Wetzel, J., Wu, C., Hu, X., Prat, J., Mudrock, E., Hettinger, R., Cortina, A. E., Biswas, R. G., Kock, F. V. C., Soong, R., Jenne, A., Du, B., Hou, F., He, H., Lundeen, R., Gilbreath, A., Sutton, R., Scholz, N. L., Davis, J. W., Dodd, M. C., Simpson, A., McIntyre, J. K., and Kolodziej, E. P.: A ubiquitous tire rubber-derived chemical induces acute mortality in coho salmon, Science, 371, 185-189, https://doi.org/10.1126/science.abd6951, 2020.

Verma, V., Wang, Y., El-Afifi, R., Fang, T., Rowland, J., Russell, A. G., and Weber, R. J.: Fractionating ambient humic-like substances (HULIS) for their reactive oxygen species activity - Assessing the importance of quinones and atmospheric aging, Atmos. Environ., 120, 351-359, https://doi.org/10.1016/j.atmosenv.2015.09.010, 2015.

Virkkula, A.: Correction of the Calibration of the 3-wavelength Par-

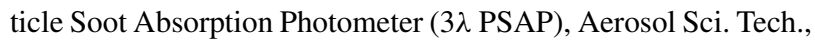
44, 706-712, https://doi.org/10.1080/02786826.2010.482110, 2010.

Wang, X., Heald, C. L., Sedlacek, A. J., de Sá, S. S., Martin, S. T., Alexander, M. L., Watson, T. B., Aiken, A. C., Springston, S. R., and Artaxo, P.: Deriving brown carbon from multiwavelength absorption measurements: method and application to AERONET and Aethalometer observations, Atmos. Chem. Phys., 16, 1273312752, https://doi.org/10.5194/acp-16-12733-2016, 2016.

Warner, J. X., Wei, Z., Strow, L. L., Barnet, C. D., Sparling, L. C., Diskin, G., and Sachse, G.: Improved agreement of AIRS tropospheric carbon monoxide products with other EOS sensors using optimal estimation retrievals, Atmos. Chem. Phys., 10, 95219533, https://doi.org/10.5194/acp-10-9521-2010, 2010.
Washenfelder, R. A., Attwood, A. R., Brock, C. A., Guo, H., Xu, L., Weber, R. J., Ng, N. L., Allen, H. M., Ayres, B. R., Baumann, K., Cohen, R. C., Draper, D. C., Duffey, K. C., Edgerton, E., Fry, J. L., Hu, W. W., Jimenez, J. L., Palm, B. B., Romer, P., Stone, E. A., Wooldridge, P. J., and Brown, S. S.: Biomass burning dominates brown carbon absorption in the rural southeastern United States, Geophys. Res. Lett., 42, 653-664, https://doi.org/10.1002/2014GL062444, 2015.

Weber, R. J., Orsini, D., Daun, Y., Lee, Y. N., Klotz, P. J., and Brechtel, F.: A Particle-into-Liquid Collector for Rapid Measurement of Aerosol Bulk Chemical Composition, Aerosol Sci. Tech., 35, 718-727, https://doi.org/10.1080/02786820152546761, 2001.

Weingartner, E., Saathoff, H., Schnaiter, M., Streit, N., Bitnar, B., and Baltensperger, U.: Absorption of light by soot particles: determination of the absorption coefficient by means of aethalometers, J. Aerosol Sci., 34, 1445-1463, https://doi.org/10.1016/S0021-8502(03)00359-8, 2003.

Werle, P., Mücke, R., and Slemr, F.: The limits of signal averaging in atmospheric trace-gas monitoring by tunable diode-laser absorption spectroscopy (TDLAS), Applied Physics B-Lasers O., 57, 131-139, https://doi.org/10.1007/BF00425997, 1993.

Wonaschütz, A., Hitzenberger, R., Bauer, H., Pouresmaeil, P., Klatzer, B., Caseiro, A., and Puxbaum, H.: Application of the Integrating Sphere Method to Separate the Contributions of Brown and Black Carbon in Atmospheric Aerosols, Environ. Sci. Technol., 43, 1141-1146, https://doi.org/10.1021/es8008503, 2009.

Zeng, L., Zhang, A., Wang, Y., Wagner, N. L., Katich, J. M., Schwarz, J. P., Schill, G. P., Brock, C., Froyd, K. D., Murphy, D. M., Williamson, C. J., Kupc, A., Scheuer, E., Dibb, J., and Weber, R. J.: Global Measurements of Brown Carbon and Estimated Direct Radiative Effects, Geophys. Res. Lett., 47, e2020GL088747, https://doi.org/10.1029/2020gl088747, 2020.

Zhang, A., Wang, Y., Zhang, Y., Weber, R. J., Song, Y., Ke, Z., and Zou, Y.: Modeling the global radiative effect of brown carbon: a potentially larger heating source in the tropical free troposphere than black carbon, Atmos. Chem. Phys., 20, 1901-1920, https://doi.org/10.5194/acp-20-1901-2020, 2020.

Zhang, X., Lin, Y.-H., Surratt, J. D., and Weber, R. J.: Sources, Composition and Absorption Ångström Exponent of Lightabsorbing Organic Components in Aerosol Extracts from the Los Angeles Basin, Environ. Sci. Technol., 47, 3685-3693, https://doi.org/10.1021/es305047b, 2013.

Zhang, Y., Forrister, H., Liu, J., Dibb, J., Anderson, B., Schwarz, J. P., Perring, A. E., Jimenez, J. L., Campuzano-Jost, P., Wang, Y., Nenes, A., and Weber, R. J.: Top-of-atmosphere radiative forcing affected by brown carbon in the upper troposphere, Nat. Geosci., 10, 486, https://doi.org/10.1038/ngeo2960, 2017. 